\title{
Perakende Mağazacılık Sektöründe Mağaza Atmosferinin Önemi: SOR Modeli Temelinde Bir Uygulama \\ (Importance of Store Atmosphere in Retail Merchandising Industry: An Application Based on SOR Model)
}

\author{
Vasviye Özlem AKGÜN iD a Muammer ZERENLER iD $b$ \\ a Selçuk Üniversitesi, İktisadi ve İdari Bilimler Fakültesi, Uluslararası ve Ticaret Bölümü, Konya, Türkiye. ozlemakgun@selcuk.edu.tr \\ b Selçuk Üniversitesi, İktisadi ve İdari Bilimler Fakültesi, İşletme Bölümü, Konya, Türkiye. zerenler@selcuk.edu.tr
}

\begin{tabular}{l} 
MAKALE BİLGİsi \\
\hline Anahtar Kelimeler: \\
Mağaza atmosferi \\
Tüketici Davranışları \\
SOR Modeli \\
Hedonik Tüketim \\
Dürtüsel Satın Alma Kararı \\
\\
Gönderilme Tarihi 21 Şubat \\
2021 \\
Revizyon Tarihi 25 Ağustos \\
2021 \\
Kabul Tarihi 30 Ağustos \\
2021
\end{tabular}

Makale Kategorisi: Araştırma Makalesi

\section{ÖZET}

Amaç - Mal ve hizmet satın alımlarında, mağaza atmosferinin satın alma kararı üzerindeki rolü son derece önemlidir. Bugünün tüketim alışkanlığında yeri oldukça önemli olan hazır giyim perakende mağazaları ele alındığında, müşterilerin çok sayıda çevresel uyarana maruz kaldıkları rahatlıkla ifade edilebilmekte, bununla birlikte alışveriş sırasında tüketicilerin çevresel uyaranlarla birlikte, duygusal ve bilişsel faktörlerden de fazlaca etkilendikleri söylenebilmektedir. Mehrabian ve Russel tarafından 1974 yılında geliştirilen ve çevre psikolojisi alanında literatüre oldukça önemli katkılar sunan "S-O-R Modeli", dış çevrenin davranışları etkileme potansiyelini ve insan davranışlarının çevre ile bağlantısını ortaya koyması bakımından pazarlama araştırmacılarına yön veren oldukça önemli bir model olarak değerlendirilmektedir. Yapılan bu çalışmanın amacı; S-O-R modeli temel alınarak, mağaza atmosferinin ortam, tasarım ve sosyal faktörler bağlamında, müşterilerin olumlu duygusal tepkileri üzerindeki etkisinin araştırılması ve bu etkinin de dürtüsel satın alma kararlarını etkileyip etkilemediğinin incelenmesidir. Bunun yanı sıra, çalışmada kişisel faktör olarak ele alınan hedonik motivasyonun bu etkileşimde üstlenmiş olduğu aracı rolün tespit edilmesi de hedeflenmiştir.

Yöntem - Kantitatif çalı̧̧ma özelliği taşıyan bu çalışmada, öncelikle araştırma konusu kapsamında ilgili literatür temel alınarak kavramsal bir çerçeve oluşturulmuş, sonrasında ise Türkiye'de zincir mağazaları bulunan ve hazır giyim sektörü alanında hizmet veren bir mağazanın 418 müşterisi üzerinde bir anket çalışması gerçekleştirilmiştir. Sonrasında ise, elde edilen 418 anket verisi SPSS AMOS 21 yapısal eşitlik modellemesi yazılımı kullanılarak yorumlanmıştır.

Bulgular - Yapılan çalışmanın sonucunda; tüketicilerin mağaza atmosferi özelliklerine ilişkin algıları ile mağaza atmosferine yönelik tepkileri arasında pozitif yönlü bir etki ve mağaza atmosferinin özelliklerine gösterilen olumlu duygusal tepkiler ve dürtüsel satın alma davranışı arasında da benzer şekilde pozitif yönlü etkinin varlığı tespit edilmiştir. Bununla birlikte hedonik motivasyonun, mağaza atmosferinin özellikleri ile tüketicilerin bu özelliklere yönelik olumlu duygusal tepkileri arasında aracı rolünün bulunması elde edilen bir diğer önemli bulgu olarak ifade edilebilmektedir.

Tartışma - Mağaza atmosferinin, müşterilerin mağaza içindeki davranışları üzerinde oldukça etkili olduğu söylenebilmektedir. Çalışmada elde edilen bulgular; mağaza atmosferinin, müşterilerin duygusal ve davranışsal tepkilerini artırmaları bağlamında kritik bir role sahip olduğunu vurgulaması bakımından literatüre katkı sunmaktadır. Özellikle pazarlama yöneticilerinin; mağaza içinde bulunan atmosfer özelliklerini müşterilerin alışveriş esnasında geçirecekleri vakti artıracak biçimde düzenlemeleri ve bu anlamda müşterilerin duygusal tepkilerini olumlu yönde geliştirmeleri, dürtüsel satın alma kararlarında etkili olabilmektedir. Bugünün modern tüketim anlayışında satın alma kararlarının haz almaya yönelik hedonik motivasyonla verilmesi ve hedonik motivasyonun aracı rolünün bulunması da geliştirilecek pazarlama stratejilerinin tüketici temelli oluşturulması gerekliliğinin önemine işaret etmektedir.

\section{ARTICLE INFO}

\section{ABSTRACT}

\section{Keywords:}

Store Atmosphere

Consumer Behaviours

SOR Model

Hedonic Consumption

Impulsive Purchasing

Decision
Purpose - In purchasing goods and services, the role of the store atmosphere in the purchasing decision is very important. Considering retail clothing stores, which have a very important place in today's consumption habits, it can be easily stated that customers are exposed to many environmental stimuli, however, it can be said that consumers are highly affected by emotional and cognitive factors as well as environmental stimuli during shopping. The "S-O-R Model", which was developed by Mehrabian and Russel in 1974 and made significant contributions to the literature in the field of environmental psychology, is considered to be a very important model that guides marketing researchers in terms of revealing the potential of the external environment to affect behaviors and the connection of human 
Received 21 February 2021

Revised 25 August 2021

Accepted 30 August 2021

Article Classification:

Research Article behavior with the environment. The purpose of this study is to investigate the effect of the store atmosphere on the positive emotional reactions of customers in the context of environment, design and social factors based on the S-O-R model and whether this effect affects impulsive purchasing decisions. In addition, it was aimed to determine the mediating role undertaken by the hedonic motivation, which is considered as a personal factor, in this interaction.

Design/methodology/approach - In this quantitative study, first, a conceptual framework on the basis of relevant literature within the scope of research topic was created, and then a survey was conducted over 418 customers of a store serving in the retail clothing sector and has chain stores all around Turkey. Afterward, 418 survey data obtained were interpreted using SPSS AMOS 21 structural equation modeling software.

Findings - As a result of the study; It was determined that there is a positive relationship between consumers' perceptions of the store atmosphere characteristics and their reactions towards the store atmosphere, and a similarly positive relationship between positive emotional reactions to the characteristics of the store atmosphere and impulsive purchasing behavior. Another finding is that hedonic motivation has a mediating role in the relationships between the characteristics of the store atmosphere (and the positive emotional reactions of consumers to these characteristics.

Discussion - It can be said that the store atmosphere has a great influence on the behavior of customers in the store. The findings of the study contribute to the literature by emphasizing that the store atmosphere has a critical role in increasing the emotional and behavioral reactions of customers. Especially, by marketing managers, regulating the atmosphere in the store in a way that increases the time customers spend while shopping and in this sense, improving the emotional reactions of the customers in a positive way can be effective in impulsive purchasing decisions. In today's modern consumption approach, making purchasing decisions with hedonic motivation to take pleasure and the intermediary role of hedonic motivation in this relationship indicates the importance of the need to create consumer-based marketing strategies to be developed.

\section{Gíriş}

Mağaza atmosferinin tüketici davranışlarını etkilediği görüşü, pazarlama literatüründe yaygın olarak kabul edilen bir görüştür. Mağaza atmosferi, tüketicilerin alışveriş yapacakları mekânın seçimi konusunda oldukça etkilidir. Bununla birlikte bazı durumlarda mağaza atmosferi unsurlarının, satın alma kararlarının verilmesinde, ürünün kendisinden dahi etkisinin yüksek olduğu durumlar söz konusu olabilmektedir (Kotler, 1973: 48-50; Areni ve Kim, 1994; Turley ve Milliman, 2000: 193; Melia ve Carida, 2020: 87). Pazarlama alanında mağaza atmosferi; belirli bir alanda bilinçli bir tasarımı oluşturmak ve böylece müşterilerin istediği etkiyi yaratmak için kullanılan bir terim olup, bir alışveriş ortamını tasarlama çabası olarak da bilinmektedir. Bu bilinçli çabanın sonucunda ise, müşteriler üzerinde duygusal bir etki yaratılması ve satın alma olasılıklarının artırılması amaçlanmaktadır (Ilmi vd., 2020: 360). Bugüne kadar mağaza atmosferi ile ilgili yapılan çalışmaların pek çoğunda; müziğin, renklerin, aydınlatmanın, kalabalığın ya da ortam kokusu gibi pek çok atmosferik uyaranın tüketiciler üzerindeki etkileri incelenmiştir. Bununla birlikte mağaza atmosferinin son derece önemli olduğu sektörlerden birisi olan hazır giyim sektöründe yaşanan şiddetli rekabet, satışlarını artırma gayesinde olan pazarlama yöneticilerine ağır yükler getirmektedir (Chen ve Hsiegh, 2011: 10057). Bu sebeple etkili ve keyifli bir alışveriş ortamı yaratabilmenin; rekabetçi pazarda başarılı olmak isteyen hazır giyim sektörü için, öncelikli bir alan haline geldiği ifade edilebilmektedir.

Bir atmosfer yaratarak mağaza içi davranışı değiştirme yeteneği, birçok hazır giyim yöneticisi ve perakende kuruluşu tarafından kabul görmektedir (Michon vd., 2005: 576). Mağaza atmosferi; ürünlerin mağazadaki sunumu, mağazada kullanılan renkler, 1şıklar, mağazadaki hava, koku, müzik, satış personellerinin görünümü ve iletişim biçimi, öteki müşterilerin mağazadaki alışveriş alışkanlıkları şeklinde müşterinin algısını etkileme potansiyeli bulunan uyarıcıların yer aldığı bir ortama karşılık gelmektedir (Arslan, 2011: 66). Hazır giyim mağazaları bağlamında, çeşitli mağaza ipuçları, müşteri deneyimini zenginleştirmede ve olumlu kılmada etkin rol oynayabilmektedir. Bu sebeple, mağaza yöneticilerinin, tüketicinin nihai olarak mağaza memnuniyetine giden yolculuğunda önemli mağaza uyaranlarını doğru biçimde tespit etmeleri bir gereklilik halini almıştır. Bu durumun yanı sıra mağaza atmosferinin, bireylerin duygularını etkilediğine ve satın alma kararlarının bu durumun sonucuna göre şekillendiğine yönelik görüşler de mevcuttur. Yapılan bu çalışmanın amacı; S-O-R modeli temel alınarak, mağaza atmosferinin ortam, tasarım ve sosyal faktörler bağlamında, müşterilerin olumlu duygusal tepkileri üzerindeki etkisinin araştırılması ve bu etkinin de dürtüsel satın alma kararlarını etkileyip etkilemediğinin incelenmesidir. Bunun yanı sıra, çalışmada kişisel faktör olarak ele alınan 


\section{V. Ö. Akgün - M. Zerenler 13/3 (2021) 2110-2128}

hedonik motivasyonun bu etkileşimde üstlenmiş olduğu aracı rolün tespit edilmesi de hedeflenmiştir. Özellikle perakende sektöründe mağaza atmosferinin tüketiciler üzerindeki etkisinin son derece önemli olması sebebiyle, ilgili ilişkilerin tespit edilmesi, kendilerini rakiplerinden farklı kılmak isteyen perakendecilerin uygulayabilecekleri stratejilerin tespit edilmesi açısından da literatüre katkı sunmaktadır.

\section{KAVRAMSAL ÇERÇEVE}

\subsection{Mağaza Atmosferi ve Atmosfer Değişkenlerinin Boyutları}

Alışveriş yapılan mekanların çoğu, kontrollü bir atmosferle çevrelenmiştir ve bu atmosfer, temelde çevrenin kalitesini tanımlamayı amaçlamaktadır. Bu nedenle, pazarlama literatüründeki atmosfer terimi tam olarak alıcıda satın alma olasılığını artıran, belirli duygusal etkiler yaratmak için bir satın alma ortamı tasarlama çabası olarak tanımlanmıştır (Kotler, 1973: 50; Pitt ve Musa, 2009; Nusairat, 2015: 13). Hazır giyim mağazaları bağlamında, atmosferin önemini anlamak için atmosfer terimini doğru olarak yorumlayabilmek son derece önemlidir. Yıllar boyunca mağaza atmosferi üzerine çok sayıda makale yazılmıştır. Bu çalışmalar arasında özellikle de Kotler (1973-1974) tarafından yapılan araştırmalarda mağaza atmosferinin, pazarlamacılar için ele alınması gereken önemli bir alan olarak vurgulanması atmosfer kavramını, daha çok ilgi görür hale getirmiştir. Atmosfer, bir müşterinin belirli bir mekâna girdiğinde oluşan algılamalarını ifade etmekte olup mağaza atmosferi kavramı pazarlamanın önemli unsurları arasında yer almaktadır (Kotler, 2000: 527). Bir başka ifadeyle mağaza atmosferi, müşterilerin duygularına yönelik etkiler yaratarak alışveriş yapmalarını sağlama amacına yönelik uygun ortam yaratma faaliyetidir (Tek ve Demirci, 2006: 626). Mağaza atmosferi aynı zamanda, müşterilerden istenilen davranışsal tepkiyi teşvik etmek amacıyla perakendecinin himayesinde olan bir mağazanın, tüm fiziksel ve fiziksel olmayan unsurlarıdır (Eroglu, Machleit ve Davis, 2001: 178). Mağaza atmosferi; mağazanın müşterilerine vermek istediği mesajla ilgili olup, müşterilerin mağazada kalmasını etkileyen kriterler mağaza atmosferini oluşturmaktadır (Yüksekbilgili, 2016: 449, 456). Yapılan çalışmalarda mağaza atmosferi farklı boyutlarıyla ele alınmıştır:

Pazarlama alanında atmosfer terimini ilk kez kullanan Kotler (1973-1974:51) tarafından yapılan sınıflandırmada dört temel boyut yer almaktadır. Bu boyutlar; görsel, işitsel, dokunsal ve koku alma ile ilgili olup, yapılan bu çalışma literatürdeki en erken tipoloji olarak bilinmektedir. Bitner (1992: 60) tarafından gerçekleştirilen çalışmada; çevresel koşullar, mekânla ilgili düzen ve fonksiyonellik ile işaretler, semboller ve insan eliyle yapılan sanatsal çalışmalar olmak üzere atmosferik değişkenler üç temel boyutta incelemiştir. Berman ve Evans (2013: 492) atmosfer boyutlarını; dış görünüm, genel iç mekân düzeni, mağazadaki düzen ve mağazadaki sergileme olmak üzere dört temel bileşenden oluştuğunu ileri sürmüştür. Bu bileşenler arasında insan bileşenine yer verilmemiştir. D'astous (2000: 152) tarafından yapılan çalışmada; üç temel boyut yer almakta olup bu boyutlar; rahatsız edici ortam faktörleri, rahatsız edici tasarım faktörleri ve rahatsız edici sosyal faktörler olarak ifade edilebilmektedir. Assafe ve Alhidari (2019: 123) ise yaptıkları çalışmada mağaza atmosferi boyutlarını; düzen, renklendirme ve temizlikten oluşan tasarım faktörleri, aydınlatma ve müzikten oluşan ortam faktörleri ve müşteri hizmetlerinden oluşan sosyal faktörler olmak üzere üçlü bir sınıflandırmaya tabi tutmuştur. Bu sınıflandırmalar dışında; Turley ve Milliman (2000: 194) tarafından yapılan mağaza atmosferiyle ilgili araştırma, alana katkı sağlaması ve pek çok çalışmaya da kaynak teşkil etmesi bakımından oldukça önemlidir. Turley ve Milliman'a göre mağaza atmosferi; genellikle belirli tüketici tepkilerini uyandırmak için tasarlanmış, müşterilerin satın alma olasılıklarını artıran, perakende satış alanlarının özellikle duyulara hitap eden niteliklerini tanımlamaktadır. Şekil 1'de iki araştırmacı tarafından geliştirilen atmosfer değişkenlerine yer verilmiştir. 

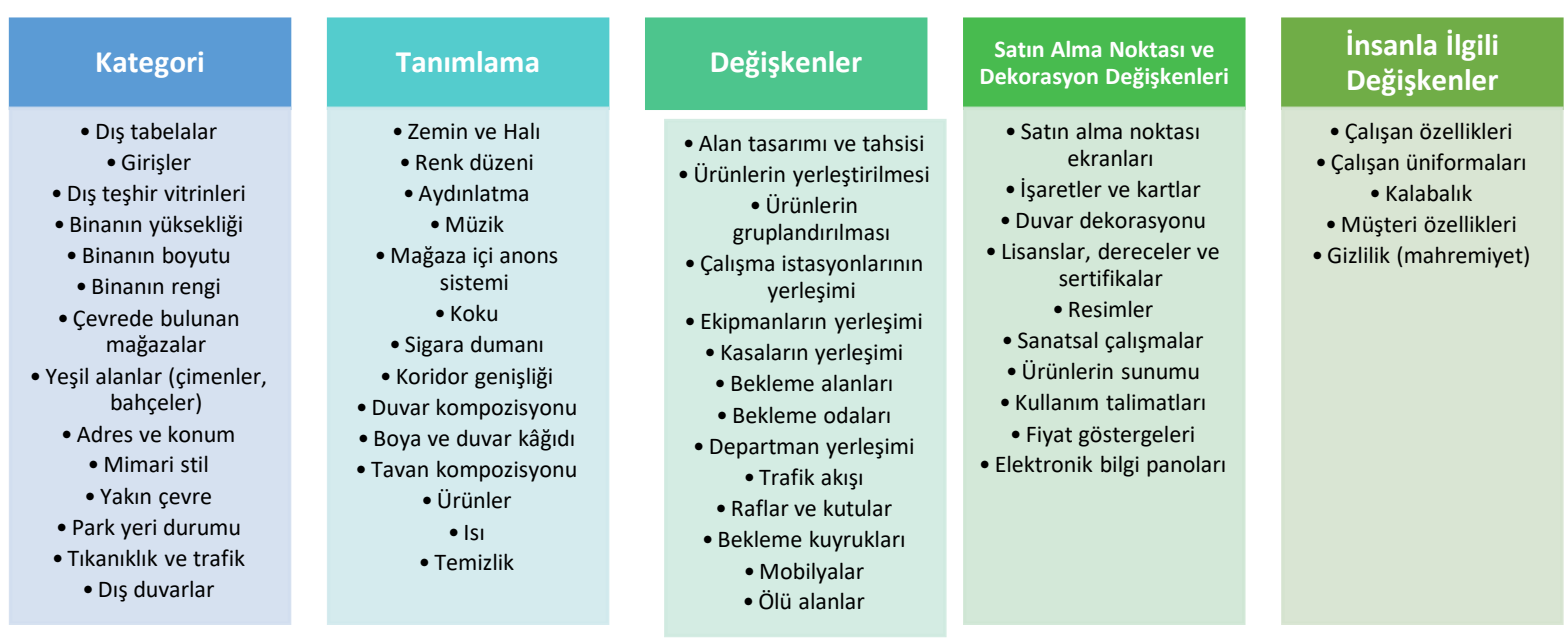

Şekil 1. Turley ve Milliman'ın (2000) Mağaza Atmosfer Değişkenleri Sınıflandırması

Kaynak: (Turley ve Milliman, 2000: 194).

Mağaza atmosferinde yaygın olarak kullanılan ve alana önemli katkılar sunan bir diğer sınıflandırma da Baker (1986: 80) tarafından ortaya koyulmuştur. Şekil 2'de gösterildiği haliyle Baker, ortam faktörleri, tasarım faktörleri ve sosyal faktörler olmak üzere çevresel faktörleri üç ana grupta incelemiştir.

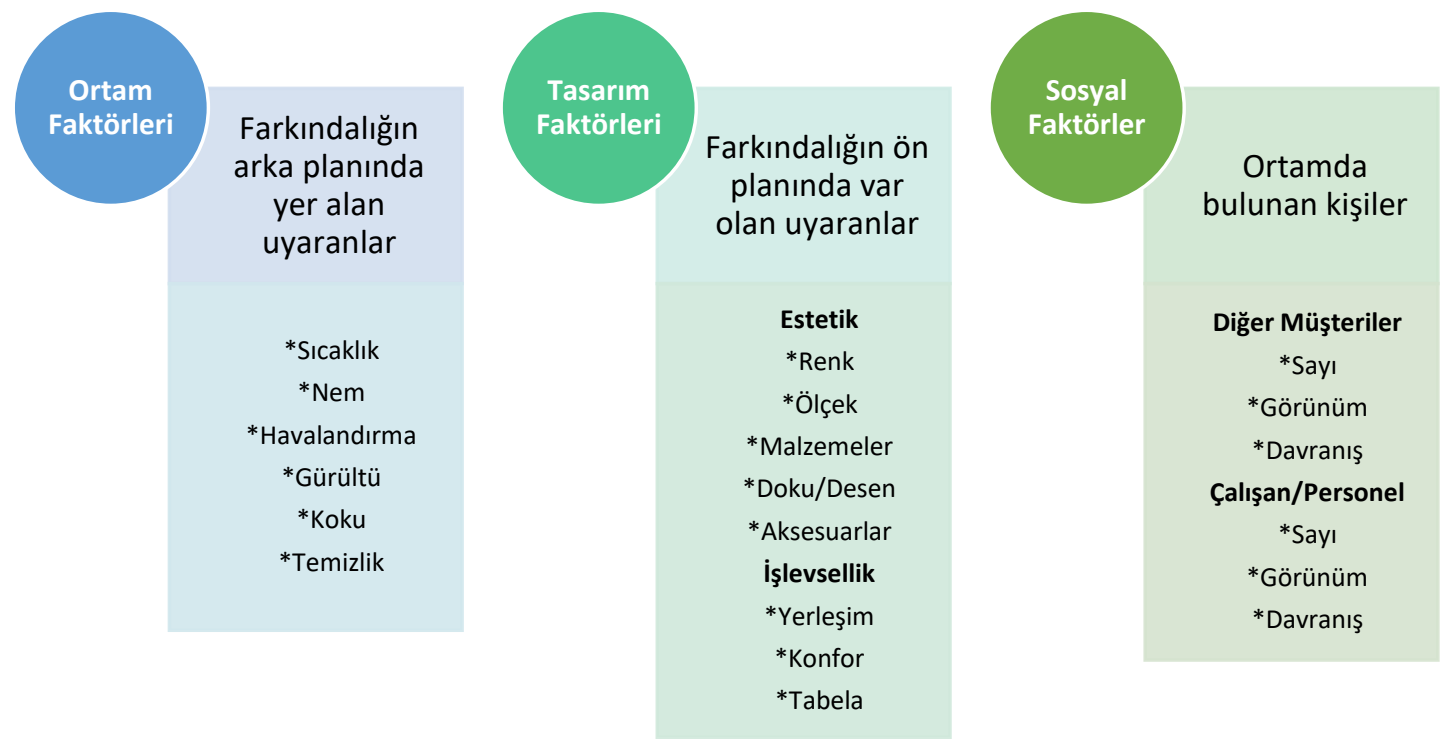

Şekil 2. Baker'in (1986) Mağaza Atmosfer Değişkenleri Sınıflandırması

Kaynak: (Baker, 1986: 80).

Geçmişten bugüne farklı araştırmacılar tarafından yapılan bu ve benzer çalışmalardan anlaşılabileceği üzere, mağaza atmosferi değişkenlerinin çok çeşitli boyutları ile ele alınabilmesi mümkündür. Bu noktada mağaza yöneticilerinin üzerinde hassasiyetle durması gereken en önemli konular arasında, mağaza atmosferi değişkenlerinin mümkün olduğunca müşterinin ilgisini çekebilecek ve müşterilerin olumlu duygusal tepkilerine katkı sağlayabilecek şekilde düzenlenmiş olması yer almaktadır.

\subsection{Mehrabian ve Russel'in Çevresel Psikoloji Modeli (S-O-R Paradigması)}

Çevresel faktörlerin, kişilerin duygularını etkilemesi ve bu durum sonucunda da davranışların etkilenmesi hakkında yapılan çok sayıda çalı̧̧ma bulunmaktadır. Özellikle atmosfer, fiziksel tasarım ve dekorasyon unsurlarının tüketiciler ve çalışanlar üzerindeki etkisi, sıklıkla araştırma konusu olmuştur. Bu çalışmalar arasında pazarlama literatürüne adapte edilen ve tüketicinin duyguları ile mağaza atmosferi unsurlarını ortaya çıkarmaya dönük olarak pek çok çalışmaya yön veren temel model ise, Houston ve Rothschild (1977: 3) tarafından oluşturulan ve birey, durum ve karar verme etkileşimini inceleyen, uyarıcı (stimulus)organizma(organism)-tepki(response) $\quad(\mathrm{S}-\mathrm{O}-\mathrm{R})$ modeli/paradigmasıdır. $\mathrm{Bu}$ paradigmadan etkilenen 
Mehrabian ve Russel (1974) duyguları; memnuniyet (pleasure), harekete geçme (arousal) ve hakimiyet boyutlarıyla açıklamaya çalıştıkları P-A-D modelini sonrasında S-O-R paradigması çerçevesinde tekrar şekillendirmiştir (Bakırtaş, 2013: 47). Mehrabian ve Russel tarafından revize edilen ve "Çevresel Psikoloji Modeli" olarak da bilinen "S-O-R" paradigması temelinde oluşturulan yeni model, çevrenin, bireyler olarak davranışları etkileme mekanizmasını açıklamanın alternatif bir yolu şeklinde ifade edilebilmektedir ve Stimulus- Organism- Response modeli; çevrenin, bir kişinin iç değerlendirmesine neden olan ve ardından bir tepki oluşmasına sebep olan bir dizi işaretten oluşan uyarıcının varlığına işaret etmektedir.

Şekil 3'te S-O-R modeli ve unsurları yer almaktadır.
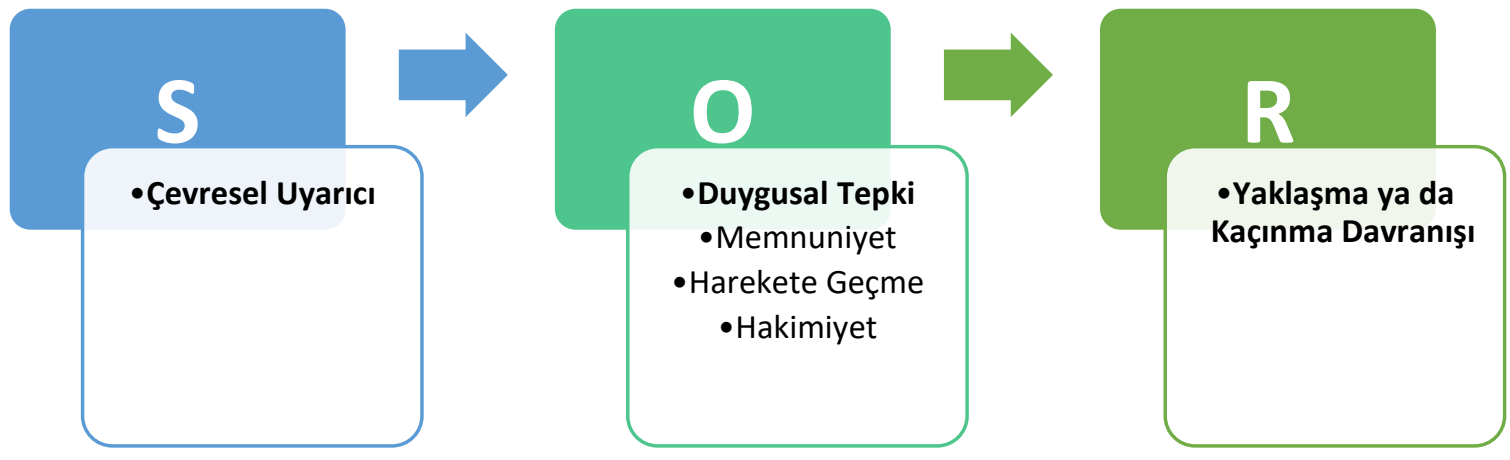

Şekil 3. Mehrabian ve Russel'in S-O-R Modeli

Kaynak: (Mehrabian ve Russel,1974: 8).

Model, bileşenler (uyaran-organizma-tepki) arasındaki mantıksal neden ve sonuç ilişkilerinden oluşan bir akışı takip etmektedir. Daha spesifik olarak ilgili model; çevresel faktörlerin (S); bireylerin iç durumlarını (O) ve dolayısıyla yaklaşma/kaçınma davranışını (R) etkilediği bir süreci açıklamaktadır. Mehrabian ve Russel tarafından adapte edilen S-O-R modelinde yer alan uyarıcılar; bireyi uyandıran etkilere işaret etmektedir (Eroglu vd. 2001: 179). Bir başka deyişle bu uyarıcılar; bireylerin iç durumları üzerinde değişen etkiye sahip herhangi bir faktöre karşılık gelmektedir ve model alışveriş merkezleri gibi perakende bağlamında müşteri davranışsal tepkilerini araştırmak için uygulandığında, alışveriş ortamının bileşenleri daha sonra uyarıcı olarak kabul edilebilmektedir (Chang vd., 2011: 237; Nusairat, 2015: 22). Mevcut literatüre yönelik araştırma sonuçlarına göre, uyarıcının somut veya soyut olma durumunun tüketicinin uyarıcıya yönelik oluşabilecek tepkisini farklılaştırmadığı, bu duruma ek olarak uyarıcının daha iyi niteliklere sahip olmasının genel olarak tüketicilerin daha olumlu bir duygusal pozisyona ulaştırılmasında ve bu durumla ilişkili olarak da daha fazla yaklaşma davranışı (mağazada vakit geçirme süresinin artması, daha çok satın alma eyleminin gerçekleşmesi vb.) sergilemelerinde önemli rol oynadığı ifade edilebilmektedir (Bakırtaş, 2013: 48).

S-O-R modeline göre organizma, uyaranla bireyin tepkileri arasındaki ilişkiye müdahale eden duygusal ve bilişsel aracı durumlar ile süreçler tarafından temsil edilmektedir. Burada alışveriş yapan tüketicilerin etkilenme durumları ve tepkiler bir dizi boyutta kavramsallaştırılabilmektedir (Eroglu vd. 2001: 180). Modelde yer alan çevreye verilen duygusal tepkiler (a) memnuniyet; belli bir durumda mutluluk, neşe veya memnuniyet düzeyi şeklinde çevreye verilen tepkilerle ilgili sözlü ifadelerle ölçülebilen memnuniyet (b) harekete geçme; bir kişinin belirli bir durumda mutluluk veya aktiflik seviyesi şeklinde daha geniş bir sözlü yargı ile ölçülebilen harekete geçme (c) hakimiyet; bir katılımcının çevresel bir durumda baskın ve etkili olmaya istekli olma biçimindeki duygularının göstergesi biçiminde ölçülebilen hakimiyet şeklinde üç boyut ile açılanabilmektedir (Hetharie vd., 2019: 2830).

Modelin üçüncü adımında yer alan unsur ise; bireyin uyaranlara karşı tepkisinin sadece yaklaşma veya kaçınma davranışı olarak tasvir edilmiştir ve (a) bir kişinin çevreyi keşfetme eğilimi, (b) çevredeki insanlarla etkileşime girme isteği ve (c) çevreden memnuniyet düzeyi olmak üzere üç ana boyuta göre yorumlanabilmektedir (Nusairat, 2015: 23). 


\subsection{Tüketicinin Olumlu Duygusal Tepkileri Bağlamında Memnuniyet Kavramı}

Duygu, davranışı güçlü bir biçimde etkileyen ve göreceli olarak kontrol edilemeyen bir hisse karşılık gelen bir kavram olmakla birlikte, duygular genellikle çevresel olaylar tarafından tetiklenmektedir (Hetharie vd., 2019: 2830). Mehrabian ve Russel'e (1974) göre, duyguların oluşturduğu duygusal durumlar herhangi bir karmaşık düşünme olmaksızın anlık bir tepki olarak gelişmektedir. Duygular genellikle; satın alma kararlarının verilmesinde önemli faktörler olarak değerlendirilmektedir ve duygusal tatmin sağlayan olumlu duygular ve olumsuz duygular olmak üzere ikiye ayrılmaktadır (Watson ve Tellengan, 1985). Rook ve Gardner'a (1993: 2) göre, müşterilerin olumlu ruh halleri, olumsuz ruh hallerine göre dürtüsel satın almaya daha elverişlidir, fakat dürtüsel satın alma davranışının her iki ruh halinde de gerçekleşmesi söz konusu olabilmektedir. Bununla birlikte, olumsuz duygularla karşılaştırıldığında, olumlu duygulara sahip müşteriler, daha az kısıtlanmış hissetmeleri, kendilerini ödüllendirme arzuları ve daha yüksek enerji seviyeleri nedeniyle daha fazla satın alma dürtüsü sergilemektedir. Müşteri memnuniyeti, genellikle bir mal ya da hizmetin, müşterilerin beklentilerini ne ölçüde karşıladığını ifade ettiğinden, başarılı şirketlerin pek çoğu, en azından müşteri beklentilerine eşit bir performans sunma gayretindedir (Anand vd., 2019: 58). Hanai ve Oguchi (2009) müşteri tatmininin ve duygusal memnuniyetin; sevinç, heyecan, rahatlama ve onaylama duygusu biçiminde kavramsallaştırılabileceğini öne sürmüştür.

Mevcut literatürde pek çok çalışma, müşteri duygularını olumlu şekilde uyarma ve tüketici memnuniyetini artırma bağlamında mağaza atmosferinin rolüne dair önemli kanıtlar sunmaktadır. Indra (2014: 6) tarafından yapılan çalışmada, mağaza atmosferinin tüketici memnuniyeti üzerinde olumlu bir etkiye sahip olduğu tespit edilmiştir. Chang vd., (2014: 298) yapmış oldukları çalışmada, mağaza tasarım faktörleri ile müşterilerin olumlu duyguları arasında pozitif yönlü bir etki tespit etmiştir. Jani ve Han (2014: 731) tarafından yapılan çalışmada da benzer şekilde mağaza ortam koşullarının müşterilerin olumlu duygularını tetiklediği ifade edilmiştir. Spangenberg vd., (2006: 1281) mağaza ortamında bulunan hoş kokunun müşterilerin alışveriş ortamını daha olumlu değerlendirebileceğine yönelik sonuçlar ortaya koymuştur. Yoo vd., (1998: 253) tarafından yapılan bir başka araştırmada hem aydınlatmanın hem de müziğin birlikte olumlu etkiyi artırdığı tespit edilmiştir. Baker vd.'ne (1992: 328) göre, mağaza içi atmosferin sosyal boyutu, tüketicilerin harekete geçmesini pozitif yönde etkilemektedir. Hui vd., (1997: 87) mağaza içi fon müziğinin mağaza içi beklemeyle ilgili duygusal değerlendirmeleri olumlu yönde etkilediğini ifade etmiştir. Ryu ve Jang (2008: 1151) iç dizayn, ambiyans ve mağaza içi düzeninin memnuniyet duygusunu etkilediğini belirtmiştir. Barros vd. (2019) tarafından yapılan çalışmada, mağaza atmosferi faktörlerinin, tüketicilerin olumlu duygusal tepkilerini etkilediği ortaya koyulmuştur. Putra vd. (2019) gerçekleştirdikleri çalışmada; mağaza atmosferi değişkenlerinin tüketicilerin satın alma kararı üzerinde pozitif ve anlamlı bir etkiye sahip olduğu bulgusuna ulaşmıştır. Yulisetiarini ve Mawarni (2021) ise hizmet kalitesi, marka imajı ve mağaza atmosferinin müşteri memnuniyeti üzerinde doğrudan etkisi bulunduğu sonucunu elde etmiştir.

\subsection{Dürtüsel Satın Alma Davranışı}

Dürtüsel satın alma davranışı, tüketici araştırmalarında oldukça ilgi gören bir araştırma alanıdır. Herhangi bir plana dayanmadan, genellikle bir dürtünün aniden ortaya çımasının sonucunda gerçekleştirilen satın almalar dürtüsel satın alma olarak ifade edilebilmektedir (Odabaşı ve Barış, 2002: 377). Dürtüsel satın alma eğilimi, kişinin niyetsiz, ani ve de düşünmeden satın alma düzeyidir (Villi ve Kayabaşı, 2013: 147). Özellikle, bu fenomenin, araştırmalara konu olmasının sebebi, yalnızca içsel psikolojik uyaranlardan etkilenmemesi, bununla birlikte dışsal pazarla ilgili uyaranların da dürtüsel satın alma davranışı üzerinde etkisinin bulunmasıdır. Dürtüsel satın almanın çeşitli tetikleyicilerinin araştırılması sonucunda, üç ana düşünce ön plana çıkmaktadır (Iyer vd. 2020: 384):

(a) Bazı araştırmacılar, kişisel özelliklerin tüketicileri ani satın almaya yönelttiği görüşündedir. Örneğin düşünmeden hareket eden kişilerin dürtüsel satın alma eğilimleri daha fazla olup, bu özelliği göstermeyen bireylerin alışveriş esnasında dürtüsel satın alma eğilimi gösterme ihtimalleri daha düşük kabul edilmektedir. (Rook ve Hoch, 1985; Verplanken ve Herabadi, 2001: 72).

(b) Hem güdüler hem de imkânlar, dürtüsel satın alma sürecini yönlendirebilmektedir. Öznel normların yanı sıra hedonik ve faydacı güdülerin de etkilerinin belirlendiği bir araştırmada 


\section{V. Ö. Akgün - M. Zerenler 13/3 (2021) 2110-2128}

yalnızca dürtüselliğin satın almayı tetikleyecek kadar güçlü olmadığı tespit edilmiştir. Bunun yerine özdenetim başarısızlı̆̆ ile birleşen para ve zaman gibi kaynakların varlığı da dürtüsel satın alma davranışını harekete geçirmek için yeterlidir (Baumeister, 2002: 670; Hoch ve Loewenstein, 1991: 504; Vohs ve Faber, 2007: 537).

(c) Bazı araştırmalar, pazarlamanın itici gücüne odaklanmaktadır ve dürtüsel satın almanın mağaza veya raf yerleşimlerinden, çekici vitrinlerden ve mağaza içi promosyonlardan etkilenebileceğine vurgu yapmaktadır. Bu görüş ise, dürtüsel satın alma davranışının etkilenebileceğini, dolayısıyla perakendecilerin bu durumu tetiklemek için tasarlanmış pazarlama araçlarına yatırım yaptığını savunmaktadır (Mattila ve Wirtsz, 2001: 274).

Beatty ve Ferrel (1998: 161) tarafından yapılan araştırmada dürtüsel satın alma davranışının mağaza içerisinde geçirilen zaman ile paralel olduğu bulgusu elde edilmiştir. Bir başka deyişle; mağaza içindeki olumlu havanın, müşteriyi mağaza içinde bulunmaya sevk ederek dürtüsel satın alma davranışını artırdığı ifade edilebilmektedir (Fettahlığlu, 2014: 31). Garlin ve Owen (2006) tarafından yapılan bir araştırma sonucuna göre, müzik ve aydınlatma gibi, mağaza ortamı değişkenlerinin ani satın alma dürtüsünü tetikleyen en önemli öncüller arasında yer aldığı tespit edilmiştir. Özellikle kişiye hoş gelen bir arka fon müziğinin varlığı, satın alma dürtüsü yaratmada olumlu bir etkiye sahiptir. Villi ve Kayabaşı (2013: 143) mağaza atmosferi dışında, arkadaş çevresi, duygusal durum ve promosyonların da dürtüsel satın alma kararı verilmesinde etkili olduğu sonucuna ulaşmıştır. Öz ve Mucuk (2015: 37) tarafından yapılan çalışmada, dürtüsel alışveriş kararı verilmesinde hedonik tüketimin etkisi olduğu tespit edilmiştir. Tokgöz (2018: 1) ise, yapmış olduğu çalışmasında materyalist değerlerin statü tüketimi ve dürtüsel satın alma davranışı üzerinde pozitif yönde direkt etkisinin bulunduğu ve statü tüketiminin materyalist değerlerle dürtüsel satın alma davranışı arasında düzenleyici bir etkisinin bulunduğu sonucuna ulaşmıştır. Armağan vd. (2019) tarafından yapılan araştırmada; tüketicilerin dürtüsel satın alma davranışıyla, sanal mağaza atmosferi arasında istatistiki olarak anlamlı bir ilişkinin var olduğu bulgusu elde edilmiştir. Arslan ve Acar (2019) ise gerçekleştirdikleri çalışmada; mağaza atmosferini oluşturan uyarıcıların, tüketiciler üzerinde farklı etkiler bırakmasının içgüdüsel satın alımları etkilediğini vurgulamışlardır.

\subsection{Hedonik Motivasyon}

Motivasyon, bireylerin belli bir amacı yerine getirme gayesiyle kendi arzularıyla ve istekleriyle hareket etmeleridir. Bir başka deyişle motivasyon, bireyleri arzu edilen yönde davranmalarına ve eyleme geçmelerine teşvik eden, kendilerinden ya da çevrelerinden kaynaklanabilen çeşitli güdü/güdüler olarak tanımlanabilmekte ve bu güdüler de ürünün somut ve işlevsel özelliklerine yönelik somut fayda sunan faydacı güdüler ve duygusal, fiziki zevkler, hayaller ve estetik özelliklere yönelik hedonik fayda sunan hedonik güdüler olmak üzere iki grupta açıklanabilmektedir (Küçükahmet, 2000: 11; Çoban ve Keskin, 2018: 95). Soysal'a (1999: 105) göre, tüketicileri satın almaya motive eden hedonik güdüler, tüketicilerin ürünlerden zevk almalarını mümkün kılacak unsurlardır ve bu unsurlar duyuların tatmini, korunma, dinlenme, hoşça vakit geçirme, başarılı olma, beğenilme, prestij, diğerlerini mutlu etme ve yeni bilgiler edinmeyi içermektedir. Genel görüş, potansiyel müşterilerin nihai olarak satın almayı istedikleri ürünler konusunda arama yapmalarını ve satın alma eylemini gerçekleştirmeleri yönünde motive edilebilecekleri yönündedir (Önen, 2019: 1867). Ayrıca, plansız satın alma davranışını etkileyen en belirgin tüketici özellikleri arasında hedonik motivasyon gelmektedir. Hedonik motivasyonla hareket eden tüketiciler, alışverişlerini gerçekleştirirken, alışverişin eğlenceli ve aynı zamanda keyif verici yanlarıyla daha ilgilidir (Öz ve Mucuk, 2015: 43). Hedonik motivasyon, deneyim, prestij, zevk, sosyal statü, duyumlar ve sosyal imajlar gibi duygusal yönlerle daha çok ilgilenen tüketici satın alma davranışıdır (Mufarrofah ve Yuniati, 2016). Hedonik motivasyon tüketimi, genellikle ürünlerin kullanımında çoklu duygusal yaklaşımlar, mutluluk, uyanış, fantezi ve zevk gibi duygusal yaklaşım biçimindeki uyarılmayı ifade etmektedir (Ahmed, 2015: 76). Arnold ve Reynolds (2003: 80) yapmış olduğu çalışmada, alışverişin hedonik motivasyonunu incelemiş ve hedonik motivasyonun altı boyutu olduğu sonucuna varmıştır:

(a) AS (Adventure Shopping); macera alışverişi, teşvik, macera ve başka bir dünyada olma hissi için yapılan alışveriş anlamını taşımaktadır. 


\section{V. Ö. Akgün - M. Zerenler 13/3 (2021) 2110-2128}

(b) SS (Social Shopping); sosyal alışveriş, arkadaşlarla ve aile ile alışveriş yapmanın, alışveriş yaparken sosyalleşmenin ve başka kişilerle kaynaşmanın keyfini ifade etmektedir.

(c) GS (Gratification Shopping); memnuniyet alışverişi, stresten kurtulmak için alışveriş yapmak, olumsuz bir ruh halini hafifletmek için kişinin kendisine özel bir ödül şeklinde düşündüğü alışverişe karşllık gelmektedir.

(d) IS (Idea Shopping); fikir alışverişi, trendlere ve yeni modalara uyum sağlamak ve yeni ürünleri görmek için yapılan alışveriştir.

(e) RS (Role Shopping); rol alışverişi, alışveriş yapan kişilerin, başka kişiler için alışveriş yapmaktan elde ettikleri keyfi, bu aktivitenin alışveriş yapanların duyguları ve ruh halleri üzerindeki etkisi ve alışveriş yapanların başka kişiler için en iyi hediye alternatifini bulurken hissettikleri heyecan ve içten sevinci ifade etmektedir.

(f) VS (Value Shopping); değer alışverişi, indirimli ürünler için alışveriş yapmak, indirim aramak ve pazarlık yapma anlamına gelmektedir.

Tüketiciler, yeni hazları hızlı bir biçimde benimseyebilmekte ve bu hazları çabucak, o anda hak etmeye yönelik bir motivasyonla eyleme geçerek hedonik bir tüketim tarzı yaklaşımına yönelebilmektedir (Coşkun ve Marangoz, 2019: 518). Genel olarak hedonik tüketim davranışının, tüketicinin alışverişte eğlence ve zevk beklentisinin önceliğini ifade ettiği ve tüketim faaliyetlerinde önemli kabul edildiği ifade edilebilmektedir (Ünal ve Ceylan, 2008: 266). Mamuaya (2018) yapmış olduğu çalışmasında; hedonik alışveriş motivasyonunun, tüketicilerin dürtüsel satın alma davranışları üzerinde anlamlı ve olumlu bir etkisi olduğu bulgusunu elde etmiştir. Wang vd. (2021) tarafından yapılan çalışmada, hedonik motivasyonların kompulsif çevrim içi satın alma davranışına katkıda bulunduğu ortaya koyulmuştur. Porral ve Mangin (2021) gerçekleştirmiş oldukları araştırmada ise, müşterilerin hedonik alışverişte mağaza atmosferini farklı algıladıkları ve özellikle müşteri memnuniyetinin hedonik alışveriş bağlamında iç ortam ve ürün düzeni tarafından yönlendirildiğini ortaya koymuştur.

\section{YÖNTEM}

Bu araştırmanın amacı; hazır giyim perakende sektörü alanında mağaza atmosferinin, müşterilerin duygusal tepkileri bağlamında memnuniyet düzeyi üzerindeki etkisi ve bu etkinin de dürtüsel satın alma davranışı üzerindeki etkilerinin ölçülmesidir. Bu amaç doğrultusunda, S-O-R modeli ve dürtüsel satın alma literatürü kapsamında yapılan çalışma ile, hazır giyim mağaza atmosferinin temel özelliğinin tüketicilerin olumlu duygusal tepkileri ve olumlu duygusal tepkilerin de dürtüsel satın alma davranışı üzerindeki etkisi araştırılmıştır. Bununla birlikte hedonik motivasyonun mağaza atmosferi özellikleri ile tüketicilerin olumlu duygusal tepkileri arasındaki etkileşimi nasıl ve ne yönde etkilediği de incelenmeye çalışılmıştır.

\subsection{Araştırmanın Modeli}

Çalışmanın kavramsal modeli temelde, S-O-R çevresel paradigması modeline dayanmaktadır. Bu bağlamda geliştirilen model ve hipotezler şu şekildedir: 


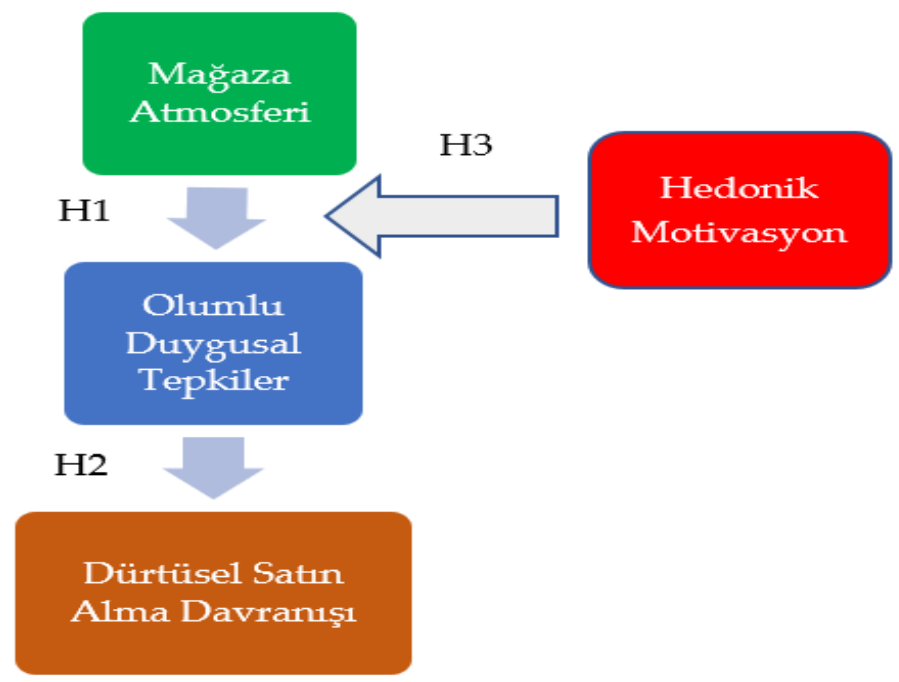

Şekil 4. Araştırmanın Kavramsal Modeli

Modelin oluşturulmasında, Mehrabian ve Russel (1974), Chang vd., (2011) ile Hetharie vd., (2019) tarafından yapılan çalışmalardan faydalanılmıştır. Bu anlamda; (a) stimulus/çevresel uyarıcı, mağaza atmosferine (b) organism/organizma, tüketicilerin olumlu duygusal tepkilerine ve (c) response/yaklaşma ya da kaçınma, dürtüsel satın alma davranışına karşıllk gelmektedir. Bununla birlikte kişisel faktörlerden hedonik motivasyonun atmosfer özellikleri ve tüketicilerin olumlu duygusal tepkileri arasındaki aracı rolüne de modelde yer verilmiştir. Bu doğrultuda geliştirilen hipotezler şu şekilde ifade edilebilmektedir:

H1: Tüketicilerin mağaza atmosferinin özelliklerine ilişkin algıları, mağaza atmosferine yönelik olumlu duygusal tepkileri pozitif yönde etkiler.

H2: Mağaza atmosferinin özelliklerine gösterilen olumlu duygusal tepkiler, dürtüsel satın alma davranışlarını pozitif yönde etkiler.

H3: Hedonik motivasyonun, mağaza atmosferinin özellikleri ile tüketicilerin bu özelliklere yönelik olumlu duygusal tepkileri arasında aracı rolü bulunmaktadır.

\subsection{Araştırmanın Evren ve Örneklemi}

Araştırmada, nicel araştırma yöntemi tercih edilmiş, bu nedenle veri toplama sürecinde anket tekniğinden faydalanılmıştır. Araştırmanın evrenini; Konya il merkezinde faaliyet gösteren hazır giyim mağazalarının müşterileri oluşturmaktadır. Araştırmanın örneklemini ise, Konya il merkezinde faaliyet gösteren ve Türkiye genelinde zincir mağazaları bulunan bir hazır giyim mağazasının Konya'da yaşayan 418 gönüllü müşterisi oluşturmaktadır. Araştırmada kullanılacak veri setini elde etmek üzere 2021 yılı Ocak Ayı içerisinde bir anket uygulaması yapılmıştır. Anketler ilgili mağazalardan çıkan müşterilerden, rastsal olarak seçilen ve ankete cevap vermek isteyenler ile yüz yüze görüşme yapılarak uygulanmıştır. Bunun yanı sıra çalışmanın yapıldığı dönemin pandemi dönemi olması sebebiyle, ilgili mağazadan alışveriş yaptığını sözlü olarak ifade eden bazı katılımcılara da anketler online ortamda ulaştırılmış ve anketlerin cevaplanması sağlanmıştır. Ana kütlenin tamamına zaman ve bütçe kısıtından dolayı ulaşma zorluğu sebebiyle, ana kütleyi temsil kabiliyetine sahip bir örneklem üzerinde çalışma yürütülmüştür. Evren büyüklüğü $(\mathrm{N})$ 1.000.000'un üzerindeyse \%95 güven aralığında gerekli örnek büyüklüğünün (S) 384 olması yeterli sayılmaktadır (Sekeran, 2003: 194). Araştırma kapsamında anketlerin eksik ya da hatalı bir biçimde doldurulma olasılığı da dikkate alınmış ve ilgili hazır giyim mağazasından alışveriş yaptığını ifade eden 418 katılımcıya anket uygulanmıştır.

\subsection{Verilerin Toplama Arac1}

Yapılan saha çalışması için hazırlanan anket formu beş bölümden oluşmaktadır. İlk bölümde; katılımcıların demografik özelliklerinin tespitine yönelik 6 soru, diğer bölümlerde ise sırasıyla; mağaza atmosferinin tespitine yönelik 18 soru (bu ölçek ortam, tasarım ve sosyal faktörlere ilişkin soru ifadeleri bağlamında değerlendirilmektedir), tüketicilerin olumlu tepkilerinin tespitine yönelik 9 soru, dürtüsel satın alma davranışının tespitine yönelik 3 soru ve hedonik tüketimle ilgili değerlendirmelerinin belirlenmesine yönelik 4 soru yer almaktadır. Ölçekte yer alan soruların oluşturulmasında konu ile ilgili yapılan literatür çalışmasının ardından mağaza atmosferine yönelik sorularda; Baker, Grewal ve Parasuraman (1994) ile Nusairat (2015), 
dürtüsel satın almaya yönelik sorularda; Beatty ve Ferrell (1998), tüketicilerin olumlu duygusal tepkilerine yönelik sorularda; Chang vd., (2011) ile hedonik motivasyona yönelik sorularda; Babin, Darden ve Griffin (1994) tarafından yapılan araştırmalardaki ölçeklerden faydalanılmıştır. Ankette 5'li Likert Ölçeği kullanılmıştır. Ölçekte yer alan numaralandırmalarda; "1 -Hiç Katılmıyorum" ve "5-Tamamen Katılıyorum" ifadelerine karşılık gelmektedir.

\subsection{Verilerin Analizi}

Oluşturulan hipotezleri test etmek için yapısal eşitlik modellemesinden faydalanılmıştır. Yapısal eşitlik modellemesi ya da İngilizce adiyla Structural Equation Modeling (SEM); belirli bir teoriye dayalı olarak gözlemlenebilen ve gözlemlenemeyen değişkenlerin nedensel ve ilişkisel bir model dahilinde tanımlanması esasına dayalı, ölçüm hatalarının dikkate alınarak gizil yapılar arası hipotezlerin test edilmesini sağlayan bir analiz tekniği olarak ifade edilmektedir (Bagozzi ve Yi, 2012; Byrne, 2001; Meydan ve Şeşen, 2015: 5). Çalışma sonucu elde edilen veriler, SPSS AMOS 21 yapısal eşitlik modellemesi yazılımı kullanılarak yorumlanmıştır.

\section{BULGULAR}

Araştırmaya katılan kişilere ait demografik özelliklerin incelenebilmesi için frekans analizi yapılmış, analiz sonuçları Tablo 1'de verilmiştir.

Tablo 1. Katılımcıların Demografik Özellikleri

\begin{tabular}{|c|c|c|c|}
\hline Cinsiyet & $\mathbf{N}$ & $\%$ & Toplam \\
\hline Kadın & 252 & 60,3 & \multirow{2}{*}{418} \\
\hline Erkek & 166 & 39,7 & \\
\hline Yaş & $\mathbf{N}$ & $\%$ & Toplam \\
\hline $18-25$ & 133 & 31,8 & \multirow{5}{*}{418} \\
\hline $26-35$ & 59 & 14,1 & \\
\hline $36-45$ & 130 & 31,1 & \\
\hline $46-55$ & 56 & 13,4 & \\
\hline 56 ve üzeri & 40 & 9,6 & \\
\hline Eğitim Durumu & $\mathbf{N}$ & $\%$ & Toplam \\
\hline İlkokul/Ortaokul & 6 & 1,4 & \multirow{4}{*}{418} \\
\hline Lise & 30 & 7,2 & \\
\hline Lisans & 274 & 65,6 & \\
\hline Lisansüstü & 108 & 25,8 & \\
\hline Medeni Durum & $\mathbf{N}$ & $\%$ & Toplam \\
\hline Bekâr & 177 & 42,3 & \multirow{2}{*}{418} \\
\hline Evli & 241 & 57,7 & \\
\hline Aylık Gelir Düzeyi & $\mathbf{N}$ & $\%$ & Toplam \\
\hline $1000-2000$ & 125 & 29,9 & \multirow{5}{*}{418} \\
\hline $2001-3000$ & 33 & 7,9 & \\
\hline $3001-4000$ & 28 & 6,7 & \\
\hline $4001-5000$ & 72 & 17,2 & \\
\hline 5001 ve üzeri & 160 & 38,3 & \\
\hline Mağazayı Ziyaret Etme Sıklığı & $\mathbf{N}$ & $\%$ & Toplam \\
\hline Nadiren & 86 & 20,6 & \multirow{4}{*}{418} \\
\hline Bazen & 192 & 45,9 & \\
\hline Sik & 126 & 30,1 & \\
\hline Çok Sik & 14 & 3,3 & \\
\hline
\end{tabular}


Araştırmaya katılım gösteren kişilerin demografik özellikleri incelendiğinde örneklem sayısının \%60,3'ünü erkek, \%39,7'sini kadın katılımcıların oluşturduğu tespit edilmiştir. Katılımcıların \%31,8'i'18-25 yaş, \%14,1'i 26-35 yaş, \%31,1'i 36-45 yaş, \%13,4'ü 46-55 yaş ve \%9,6'sı 56 üzeri yaş aralığındadır. Eğitim durumları incelendiğinde \%1,4'ünün ilkokul ve ortaokul mezunu, \%7,2'sinin lise mezunu, \%65,6'sının lisans mezunu ve \%25,8'inin lisansüstü düzeyinde olduğu gözlemlenmiştir. Katılımcıların medeni hallerinin tespitine yönelik yöneltilen soruya verilen cevaplara göre $\% 42,3^{\prime}$ ü bekâr iken $\% 57,7^{\prime} \operatorname{sinin}$ evli olduğu görülmüştür. Katılımcıların gelir düzeylerine ilişkin yapılan incelemede 1000-2000 TL arası gelire sahip kişilerin \%29,9, 2001-3000 TL arası gelire sahip kişilerin \%7,9, 3001-4000 TL arası gelire sahip kişilerin \%6,7, 4001-5000 TL arası gelire sahip kişilerin \%17,2 ve $5001 \mathrm{TL}$ ve üzeri gelire sahip bireylerin $\% 38,3$ oranında olduğu saptanmıştır. Katılımcıların mağazayı ziyaret etme sıklıklarına ilişkin soruya verilen cevaplara göre \%20,6'sı nadiren, \%45,9'u bazen, \%30,1'i sık ve \%3,3'ü çok sık ziyaret ettiğini ifade etmiştir.

Çalışmada yararlanılan “Mağaza Atmosferi Özellikleri”, “Olumlu Duygusal Tepkiler”, “Dürtüsel Satın Alma Davranışı" ve "Hedonik Motivasyon" ölçeklerinin güvenilir olup olmadığının ölçülmesi amacıyla Cronbach Alfa Katsayısından yararlanılmıştır. Ölçeklere ilişkin analizler sonucunda tespit edilen Cronbach Alfa Katsayıları Tablo 2'de gösterilmiştir.

Tablo 2. Ölçeklere İlişkin Güvenilirlik Düzeyi

\begin{tabular}{|l|c|c|}
\hline \multicolumn{1}{|c|}{ Ölçek } & Madde Sayısı & Cronbach Alfa Katsayısı \\
\hline Atmosfer Özellikleri & 18 & 0,946 \\
\hline Olumlu Duygusal Tepkiler & 9 & 0,960 \\
\hline Dürtüsel Satın Alma Davranışı & 3 & 0,833 \\
\hline Hedonik Motivasyon & 4 & 0,942 \\
\hline
\end{tabular}

İslamoğlu ve Alnıaçık (2016: 156) güvenilirlik katsayısı \%80'i geçtiğinde ölçeğin yüksek düzeyde güvenilir olduğunu ifade etmektedir. Bu bilgiler ışığında Tablo 2'ye göre; mağaza atmosferi özellikleri ölçeğinin güvenilirlik katsayısı 0,946 olarak tespit edilmiştir. Olumlu duygusal tepkiler ölçeğinin güvenilirlik katsayısı 0,960, dürtüsel satın alma davranışı ölçeğinin güvenilirlik katsayısı 0,833 ve hedonik motivasyon ölçeğinin güvenilirlik katsayısı 0,942 olarak hesaplanmıştır. Bu sonuçlar değerlendirildiğinde tüm ölçeklere ilişkin güvenilirlik katsayılarının 0,80 üzerinde olduğu ve dolayısıyla çalışmada kullanılan ölçeklerin ve ölçek boyutlarının tamamının yüksek düzeyde güvenilirliğe sahip olduğu ifade edilebilmektedir.

$\mathrm{Bu}$ araştırmaya dair oluşturulan model ile S-O-R çevresel paradigmasının üç boyutu ile hedonik motivasyon kavramları arasındaki etkiler incelemiştir. Modelde mağaza atmosferi boyutu egzojen yani bağımsız özellik gösteren değişken iken, tüketicilerin olumlu duygusal tepkileri, tüketicilerin dürtüsel satın alma davranışı ve hedonik motivasyon bağımlı özellik gösteren değişkenlerdir. Araştırma için toplanan veriler beşli likert ölçeğine bağlı kalmak koşuluyla katılımcılara yönlendirilen ifadeler ile sağlanmıştır.

Katılımclara uygulanan anket sonuçları ile; mağaza atmosferi kavramı, tüketicilerin olumlu duygusal tepkileri, tüketicilerin dürtüsel satın alma davranışı ve hedonik motivasyon kavramları arasındaki etki test edilmiştir. Bunun için yapısal eşitlik modellemesi kullanılmış ve analizler için ise AMOS 21 programından faydalanılmıştır.

Tablo 3. Mağaza Atmosferi, Tüketicilerin Olumlu Duygusal Tepkileri, Dürtüsel Satın Alma Davranışı ve Hedonik Motivasyon Yapısal Eşitlik Modeli Standart Değerleri ve Modelin Uyum İyiliği Değerleri

\begin{tabular}{|c|c|c|c|}
\hline Uyum Değerleri & İyi Uyum & Kabul Edilebilir Uyum & Modelin Değerleri \\
\hline$\left(\mathrm{X}^{2} / \mathrm{df}\right)$ & $0<\mathrm{X}^{2} / \mathrm{df} \leq 2$ & $2<\mathrm{X}^{2} / \mathrm{df} \leq 3$ & 2,885 \\
\hline RMSEA & $0<\mathrm{RMSEA} \leq 0,05$ & $0<\mathrm{RMSEA} \leq 2$ & 0,067 \\
\hline $\mathrm{GFI}$ & $0,95 \leq \mathrm{GFI} \leq 1$ & $0,90 \leq \mathrm{GFI}<0,95$ & 0,812 \\
\hline $\mathrm{CFI}$ & $0,95-\leq \mathrm{CFI} \leq 1$ & $0,90 \leq \mathrm{CFI}<0,95$ & 0,921 \\
\hline
\end{tabular}

Kaynak: (Karagöz, 2006). 


\section{V. Ö. Akgün - M. Zerenler 13/3 (2021) 2110-2128}

Anketlerden toplanan verilerin analizinde AMOS 21 programı kullanılarak Yapısal Eşitlik Modellemesi geliştirilmiştir. Yapısal Eşitlik Modellemesi birden fazla değişken arası etkilerin analiz edilmesini sağlayan ve bunları yaparken ölçüm hatalarını değerlendirebilen bir analiz metodudur. Yapısal eşitlik modellemesi için değerlendirme ölçütleri uyum indeksleridir (goodness-of-fit). Bu değerler modelin geçerliği hakkında bilgi vermektedir. Bunlardan en çok kullanılanları $\chi^{2} / \mathrm{sd}$, GFI, CFI ve RMSEA'dır.

$\chi^{2} /$ sd değeri Ki-kare $\left(\chi^{2}\right)$ değerinin serbestlik derecesine bölünmesi ile elde edilmektedir. Bu değerin $5^{\prime}$ in altında olması kabul edilebilir olarak değerlendirilirken, 3 'ün altında olması ise iyi olarak değerlendirilmektedir (Şimşek, 2007). Modelin ki-kare değeri 1474,039 serbestlik derecesi ise 511'dir. $\chi 2$ /sd veri ile model arasındaki uyumun iyiliğini ifade etmektedir. Bu değerin ise 2,885 olduğu tespit edilmiştir. GFI ve CFI değerlerinin 1 ile 0,95 değerleri arasında olması iyi olarak değerlendirilirken, 0,95 ile 0,90 arasında olması kabul edilebilir olarak değerlendirilmektedir. RMSEA değerinin ise 0,05 ile 0 arasında olması iyi olarak değerlendirilirken, 0 ile 2 arasında olması kabul edilebilir olarak değerlendirilmektedir. Buna göre önerilen modelin diğer uyum indeksleri de incelendiğinde GFI (Uyum iyiliği indexi) değeri 0.81, CFI (Karşılaştırmalı uyum indexi) değeri 0.92 ve RMSEA (Kök ortalama kare yaklaşımı hatası) değeri ise 0,067 olarak tespit edilmiştir.

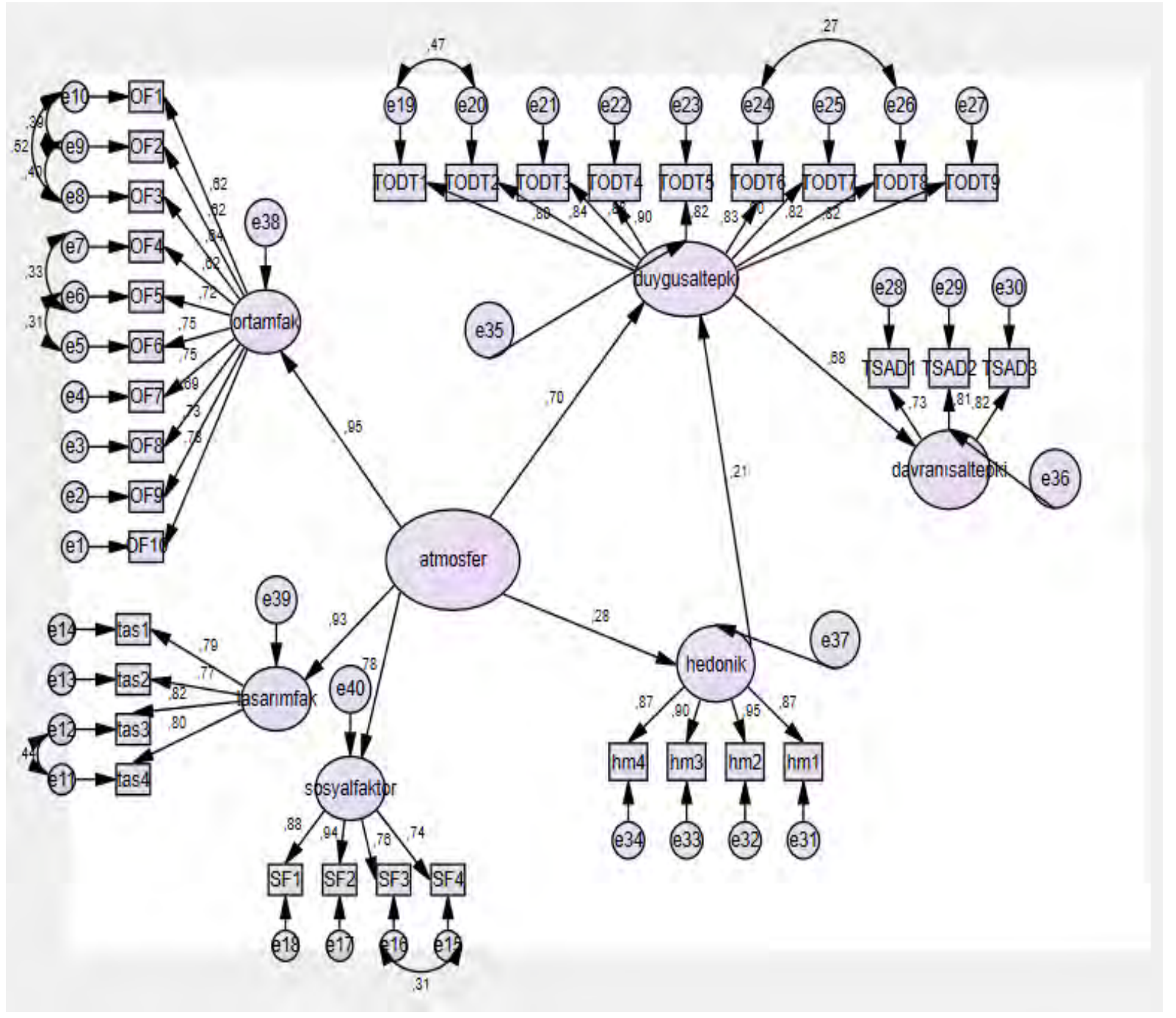

Şekil 5. Yapısal Eşitlik Modeli

Oluşturulan Yapısal Eşitlik Modellemesi sonucu elde edilen regresyon katsayıları Tablo 4'te sunulmuştur. 
V. Ö. Akgün - M. Zerenler 13/3 (2021) 2110-2128

Tablo 4. Yapısal Eşitlik Modellemesi Regresyon Katsayıları

\begin{tabular}{|l|c|c|c|c|c|c|}
\hline \multicolumn{1}{|c|}{ Hipotez } & $\begin{array}{c}\text { Standardize } \\
\boldsymbol{\beta}\end{array}$ & $\begin{array}{c}\text { Standart } \\
\text { Hata }\end{array}$ & $\begin{array}{c}\text { Kritik } \\
\text { Oran }\end{array}$ & $\mathbf{P}$ & Sonuç & $\mathbf{R}^{\mathbf{2}}$ \\
\hline $\begin{array}{l}\text { H1: Tüketicilerin mağaza atmosferinin } \\
\text { özelliklerine ilişkin algıları, mağaza } \\
\text { atmosferine yönelik olumlu duygusal } \\
\text { tepkileri pozitif yönde etkiler. }\end{array}$ & 0,708 & 0,056 & 12,577 & $* * *$ & KABUL & 0,63 \\
\hline $\begin{array}{l}\text { H2: Mağaza atmosferinin özelliklerine } \\
\text { gösterilen olumlu duygusal tepkiler, } \\
\text { dürtüsel satın alma davranıslarını pozitif } \\
\text { yönde etkiler. }\end{array}$ & 0,720 & 0,062 & 11,612 & $* * *$ & KABUL & 0,42 \\
\hline
\end{tabular}

Yapısal eşitlik modellemesi regresyon katsayıları tablosundaki rakamlardan da anlaşılacağı üzere H1: "Tüketicilerin mağaza atmosferinin özelliklerine ilişkin algıları, mağaza atmosferine yönelik olumlu duygusal tepkileri pozitif yönde etkiler." hipotezi ile H2: "Mağaza atmosferinin özelliklerine gösterilen olumlu duygusal tepkiler, dürtüsel satın alma davranışlarını pozitif yönde etkiler." hipotezi kabul edilmiştir. Daha sonra, araştırma modelinde yer alan hedonik motivasyon değişkeninin aracılık etkisini test edebilmek amacıyla Şekil 6’ da gösterilen ayrı bir model kurulmuştur.

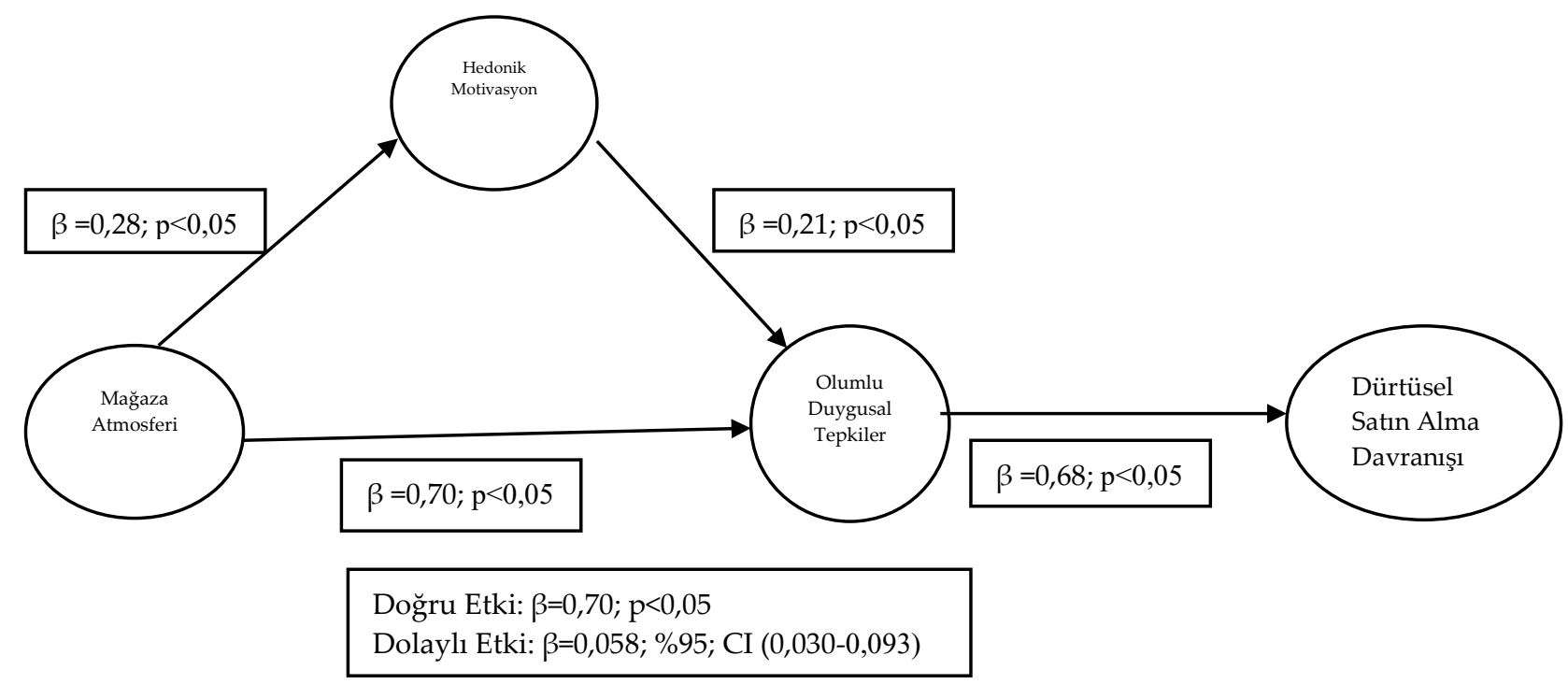

Şekil 6. Hedonik Motivasyon Kavramının Aracılık Etkisi

Not: Standardize edilmemiş beta katsayıları raporlanmıştır.

Tablo 5. Hedonik Motivasyonun Aracılık Etkisi Modellemesi Doğrudan ve Dolaylı Etkiler

\begin{tabular}{|r|c|c|c|c|c|}
\hline $\begin{array}{r}\text { Bağımsız } \\
\text { Değişkenler }\end{array}$ & $\begin{array}{c}\text { Bağımlı } \\
\text { Değişken }\end{array}$ & $\begin{array}{c}\text { Doğrudan } \\
\text { Etki }\end{array}$ & Dolaylı Etki & VAF Değeri & $\begin{array}{c}\text { Aracı } \\
\text { Etki }\end{array}$ \\
\cline { 1 - 5 } $\begin{array}{r}\text { Mağaza } \\
\text { Atmosferi }\end{array}$ & $\begin{array}{c}\text { Olumlu } \\
\text { Duygusal }\end{array}$ & $\begin{array}{c}0,70 \\
(\mathrm{p}<0,05)\end{array}$ & $\begin{array}{c}0,28^{*} 0,21=0,58 \\
(\mathrm{p}<0,05)\end{array}$ & $0,58 /(0,58+070)=0,45$ & $\begin{array}{c}\text { Kismi } \\
\text { Etki }\end{array}$ \\
\cline { 1 - 4 } $\begin{array}{r}\text { Hedonik } \\
\text { Motivasyon }\end{array}$ & Tepkiler & $\begin{array}{c}0,21 \\
(\mathrm{p}<0,05)\end{array}$ & - & - & - \\
\hline
\end{tabular}

Buna göre, öncelikle YEM modeli ile mağaza atmosferi ile tüketicilerin olumlu duygusal tepkileri arasındaki etki incelenmiş $(\beta=0,70 ; p<0,05)$ ve aralarındaki etkinin anlamlı olduğu tespit edilmiştir. Aracı değişken olan değişkenin (hedonik motivasyon) mağaza atmosferi ile tüketicilerin olumlu duygusal tepkileri değişkeni 


\section{V. Ö. Akgün - M. Zerenler 13/3 (2021) 2110-2128}

arasındaki yol katsayısının hâlâ anlamlı olduğu tespit edilmiştir $(\beta=0,058 ; p<0,05)$. YEM modeli uyum iyiliği değerleri eşik değerlerinin üzerinde olduğu için modelin veri ile uyumunun kabul edilebilir olduğu söylenebilmektedir (X2/sd[1474/511] $=2,885 ; \mathrm{p}<0,05 ; \mathrm{RMSA}=0,067 ; \mathrm{CFI}=0,921 ; \mathrm{GFI}=0,816)$. Bootstrap \%95 güven aralığında 0 (sıfır) değerini kapsamadığından test edilen aracılık modeli istatiksel olarak anlamlıdır. Bu sonuç dikkate alındığında hedonik motivasyon değişkeninin mağaza atmosferi ile tüketicilerin olumlu duygusal tepkileri değişkenleri üzerindeki dolaylı etkisinin anlamlı olduğu tespit edilmiştir ( $\beta=0,057 ; \% 95$; BCA CI [0,030-0,093]). Buna göre aracı değişken modele dahil edilerek kurulan hipotez H3: "Hedonik motivasyonun, mağaza atmosferinin özellikleri ile tüketicilerin bu özelliklere yönelik olumlu duygusal tepkileri arasında aracı rolü bulunmaktadır, şeklindeki aracılık etkisi hipotezi desteklenmiştir. Dolayısıyla yapılan Bootstrapping işlemi sonucunda, mağaza atmosferi değişkeni ile tüketicilerin olumlu duygusal tepkileri değişkeni üzerinde hedonik motivasyon değişkenin aracı rolünün anlamlı olduğu belirlenmiştir. Aracilık etkisinin ölçülmesinde ise VAF (Variance Account For) değeri kullanılmıştır. VAF değerinin 0,80'nin üzerinde olması tam aracı etki olduğunu, 0,20-0,80 arasında olması kısmi aracı etki olduğunu ve 0,20' den küçük olması ise aracılık etkisinin olmadığını göstermektedir (Hair vd.,2014). Modelimizin VAF değeri Tablo 5'te gösterilmiştir. Ayrıca dolaylı etkinin gerçek olup olmadığını test eden Sobel Testi $p<0,05$ değeri anlamlı çıkmıştır.

\section{SONUÇ ve TARTIŞMA}

Satın alma kararında mağaza atmosferi müşterilerin mağaza içindeki davranışları üzerinde oldukça etkilidir. Bununla birlikte; müşteri davranışlarını etkileyen bu kritik rol, pazarlamacılar tarafından kabul görse ve pek çok araştırmaya konu olsa da davranışları etkilemeye sebep olan asıl faktörlerin belirlenmesi ve etki düzeyleri halen ilgi çekici bir araştırma alanıdır. Özellikle belirli davranışları değiştirme ve şekillendirebilme yeteneğine sahip atmosferik uyaranlar, müşteriler üzerinde beklenmedik etkiler yaratmak, müşteri memnuniyetini artırmak ve kâr rakamlarında iyileştirmeler sağlamak için pazarlama yöneticilerine önemli ipuçları sunmaktadır. Mağaza atmosferinin müşterilerin ruh hallerini olumlu yönde teşvik etmesi, bulunduğu ortamda müşterilerin kendilerini rahat hissetmeleri ve mağazada daha çok vakit geçirme istekleri, dürtüsel satın alma kararları verilmesinde önemli bir teşvik edici konumundadır. Ayrıca, bugünün modern tüketim anlayışının bir yansıması olarak ifade edilebilen ve en basit haliyle, tüketim faaliyetlerinde günümüz müşterisinin mal ya da hizmet alırken sadece fiziksel tatmin hissi ile hareket etmediği, bunun ötesinde psikolojik olarak da haz alma güdüsü ile satın alma kararlarını vermesi esasına dayanan hedonik motivasyon da müşterilerin alışveriş yaparken satın alma kararlarında önemli bir davranış biçimi olarak değerlendirilmektedir.

Yapılan bu çalışma; Mehrabian ve Russel'in (1974) S-O-R modeli temel alınarak gerçekleştirilmiştir. Bu model doğrultusunda mağaza ortamının müşterilerin olumlu duygusal tepkilerini etkileyen bir uyarıcı görevi gördüğü ve bu durumun da tüketicilerin dürtüsel satın alma davranışlarını etkilediği varsayımı altında araştırmanın kavramsal modeli oluşturulmuştur. Modelin detaylı olarak açıklandığı çalışma kapsamında uyarıcı faktörlerin değerlendirilmesinde Baker'ın (1986) alışveriş tipolojisi benimsenmiş ve mağaza atmosferini oluşturan faktörler; ortam, tasarım ve sosyal faktörler biçiminde üçlü bir gruplandırmaya tabi tutulmuştur. Bu tipolojinin rehberliğinde müşteri alışveriş deneyimini ve davranışını etkileme bağlamında, mağaza atmosferini meydana getiren faktörlerle ilgili literatür çalışmasına yer verilmiştir. Ayrıca günümüz modern tüketiminin bir yansıması olarak değerlendirilebilen hedonik tüketimin buradaki aracı rolü belirlenmeye çalışılmış ve bu aracı rol değişkeni, araştırmanın kavramsal modeline dahil edilmiştir. Bu kapsamda Türkiye genelinde zincir mağazaları bulunan hazır giyim sektöründe hizmet veren bir mağazanın müşterileri ile anket uygulaması gerçekleştirilmiş, elde edilen 418 anket verisi istatistiki yöntemlerle analiz edilmiştir. Yapılan çalışmanın sonucunda; tüketicilerin mağaza atmosferinin, özelliklerine ilişkin algıları ile, mağaza atmosferine yönelik tepkileri arasında ve mağaza atmosferinin özelliklerine gösterilen olumlu duygusal tepkiler ve dürtüsel satın alma davranışı arasında pozitif yönlü etkinin varlığı, bununla birlikte hedonik motivasyonun ise, mağaza atmosferinin özellikleri ile tüketicilerin bu özelliklere yönelik olumlu duygusal tepkileri arasında aracı rolünün bulunduğu tespit edilmiştir. Bu anlamda çalışmada test edilen modelin; perakende sektörü alanındaki mağaza yöneticilerine, arzu edilen müşteri deneyimini ve memnuniyetini yaratacak mağaza atmosferini stratejik biçimde tasarlayabilmeleri hususunda katkı sunacağ1 ifade edilebilmektedir. 


\section{V. Ö. Akgün - M. Zerenler 13/3 (2021) 2110-2128}

Çalışmada elde edilen bulgular; mağaza atmosferinin, müşterilerin duygusal ve davranışsal tepkilerini etkileme noktasında kritik bir role sahip olduğunu vurgulaması bakımından literatüre katkı sunmaktadır. Yapılan çalışma sonucunda elde edilen bu önemli bulgu, daha önce konuyla ilgili yapılan çalışmaları destekler nitelikte gerçekleşmiştir (Turley ve Millian, 2000; Kusumowidagdo vd., 2012; Mattila ve Wirtz, 2008; Michon vd., 2005; Bozpolat, 2017; Hetharie vd., 2019; Chang vd. 2011). Çalışmada elde edilen ilk bulgu; tüketicilerin mağaza atmosferinin özelliklerine ilişkin algıları ile, mağaza atmosferine yönelik olumlu duygusal tepkileri arasında pozitif yönlü bir etki olduğu şeklindedir. Herhangi bir mağazada atmosferin, çok çeşitli uyaranlar içerdiği söylenebilmektedir. Tüketicilerin bu uyaranları içeren perakende ortamını olumlu olarak algıladıklarında, daha olumlu duygusal tepkiler verme eğiliminde oldukları gösterilmiştir. Bu kapsamda, mağazada çalınan ve kulağa hoş gelen bir fon müziğinin, kullanılan renklerin uyumunun, ortam ısısının ve hava kalitesinin uygun olmasının, ürünlerin düzenli görünümünün ya da mağaza çalışanlarının kişisel ilgi ve samimiyet göstermesinin, müşterilerin alışveriş ortamı değerlendirmesinde oldukça önemli bir yere sahip olduğu ifade edilebilmektedir.

Bununla birlikte, çalışma sonucu elde edilen diğer bulgular arasında yer alan; olumlu duygusal tepkilerin müşterilerin dürtüsel satın alma kararlarında pozitif etkiye sahip olması değerlendirildiğinde; perakende ortamına daha olumlu duygusal tepkiler gösteren tüketicilerin, dürtüsel satın alma olasılıklarının da daha yüksek olduğu ortaya koyulmuştur. Başka ifade ile; tüketiciler, ilgili perakende ortamlarında, heyecanlı, hevesli, ilgili, memnun vb. duygu ve düşüncelere sahip olduklarında dürtüsel olarak satın alma ihtimalleri de daha yüksektir.

Hedonik motivasyonun; mağaza atmosferi ve tüketicilerin bu kapsamda geliştirdikleri olumlu duygusal tepkiler arasındaki aracılık rolünün varlığı ise, perakende atmosferi ile tüketicilerin bu atmosfere yönelik olumlu duygusal tepkileri arasındaki etki üzerinde hedonik motivasyonun aracllı rolünün bulunduğunu ortaya koymaktadır. Hedonik motivasyonun üstlenmiş olduğu moderatörlük rolü, mağazanın sahip olduğu atmosfer özelliklerinin iyileştirilmesi sayesinde, tüketicilerin boş zamanlarını bu mağazalarda alışveriş yaparak geçirmeleri ya da alışverişi bir eğlence aracı olarak görmeleri şeklinde farklı motivasyonlar aracılığıyla daha olumlu duygusal tepkiler geliştirmelerine katkı sunmaktadır.

Çalı̧̧ma sonunda elde edilen bulgular, mağaza yöneticilerine uygulayacakları pazarlama politikalarına yol gösterme bağlamında, özellikle de tüketici temelli kararlar verilmesi açısından önem teşkil etmektedir. Mağaza deneyimine yönelik olarak özellikle, iç dizayn, ambiyans, mağaza içi düzen ve personelin yaklaşımı başta olmak üzere müşteri memnuniyetini artıracak düzenleme ve uygulamalara ağırlık verilmesi gerektiği söylenebilmektedir. Alışveriş esnasında olumlu ruh hali içinde olan bireylerin, bir başka deyişle duygusal memnuniyete sahip tüketicilerin satın almaya daha istekli olmasından hareketle pazarlama yöneticilerine, tüketicilerin ruh hallerini pozitif yönde etkileyen, mağazada kalma sürelerini artıran duyusal uyaranları etkin bir biçimde kullanarak bu süreci geliştirmeleri önerilebilmektedir. Genel olarak çalışma kapsamında tartışılan tüm değişkenlerin, pazar payını artırmak ve perakende sektörüne yönelik yenilikçi politikalar uygulamak açısından hazır giyim perakende yöneticilerine önemli katkılar sunacağı rahatlıkla ifade edilebilmektedir. Çalışmada birtakım kısıtlamalar bulunmakla birlikte; bu kısıtlamaların en önemlileri, Türkiye çapında faaliyette bulunan bir hazır giyim mağazasının örneklemi olarak yalnızca Konya ilindeki katılımcıların belirlenmiş olmasıdır. Gelecekte bu konu üzerinde yapılacak çalışmalarda araştırmacılara, uygulamanın farklı örneklemler üzerinde test edilmesi önerilebilmektedir. Ayrıca, mağaza atmosfer değişkenlerinin sektöre göre farklılık arz edebileceği görüşünden hareketle, araştırmanın hazır giyim sektörü dışında da farklı sektörlerde yürütülmesi müşteri deneyiminin zenginleştirilmesi bağlamında geliştirilecek stratejilerde ilgili taraflara yol gösterici olabilecektir. 


\section{V. Ö. Akgün - M. Zerenler 13/3 (2021) 2110-2128 \\ KAYNAKÇA}

Ahmed, K. A. (2015). Utilitarian and hedonic motives of university students in their online shopping: Agender based examination, Global Managing Review, 9(4), 75-91.

Anand, T., Ramachandran, J., Sambasivan, M. and Batra, S.G. (2019). Impact of hedonic motivation on consumer satisfaction towards online shopping: Evidence from Malaysia, E-Service Journal, 11(1), 56-88.

Areni, C. S. and Kim, D. (1994). The influence of in-store lighting on consumers' examination of merchandise in a wine store, International Journal of Research in Marketing, 2, 117-125.

Armağan, E., Danışman, E. ve Öngen, B.H. (2019). Sanal mağaza atmosferinin anlık satın almaya etkisi, Atatürk Üniversitesi İktisadi ve İdari Bilimler Dergisi, 33(1), $29-49$.

Arnold, M. J., and Reynolds, K. E. (2003). Hedonic shopping motivations, Journal of Retailing, 79(2), 77-95.

Arslan, K. ve Acar, N. (2019). Uyarıcıların önemi: Mağaza atmosferinin içgüdüsel satın alma üzerindeki etkileri, İstanbul Ticaret Üniversitesi Girişimcilik Dergisi, 3(6), 132-142.

Arslan, M. (2011). Mağazacılıkta Atmosfer, İstanbul, Beta Basım Yayın Dağıtım.

Assafe, A.J. and Alhidari, M.A. (2019). Applying a scale for measuring store equity in the Kingdom of Saudi Arabia, International Journal of Marketing Studies, 11(1), 122-133.

Babin, B.J., Darden, W.R. and M. Griffin (1994). Work and/or fun: Measuring hedonican dutilitarian shopping value, Journal of Consumer Research, 20, 644-665.

Bagozzi, P.R. and Youjae Y. (2012). Specification, evaluation, and Interpretation of structural equation models, Journal of The Academy of Marketing Science, 40(1), 8-34.

Baker, J. (1986). The Role of The Environment in Marketing Services: The Consumer Perspective, Czepiel, C. Congram and J. Shanahan (Eds.), The Services Challenge: Integrating For Competitive Advantage, Chicago, American Marketing Association, 79-84.

Baker, J., Grewal, D. and Parasuraman, A. (1994). The influence of store environment on quality inferences and store image, Journal of The Academy of Marketing Science, 24(4), 328-39.

Baker, J., Levy, M. and Grewal, D., (1992). An experimental approach to making retail store environmental decisions, Journal of Retailing, 68(4), 445-460.

Bakırtaş, H. (2013). S-O-R paradigması temelinde mağaza atmosferi ve duyguların pazarlamadaki önemi: Bir literatür incelemesi, KMÜ Sosyal ve Ekonomik Araştırmalar Dergisi, 15 (25), 47-55.

Barros, L.B.L., Petroll, M.L. M., Damacena, C. and Knoppe, M. (2019). Store atmosphere and impulse: A crosscultural study, International Journal of Retail \& Distribution Management, 47(8), 817-835.

Baumeister, R. F. (2002). Yielding to temptation: Self-control failure, impulsive purchasing and consumer behavior, Journal of Consume Research, 28(4), 670-676.

Beatty, S. E., and Ferrell, M. E. (1998). Impulse buying: Modeling its precursor, Journal of Retailing, 74(2), 169191.

Berman, B. and Evans, J. R. (2013). Retail Management: A Strategic Approach. England, Pearson Education.

Bitner, J. M. (1992). Servicescapes: The impact of physical surroundings on customers and employees, Journal of Marketing, 56(2), 57-71.

Bozpolat, C. (2017). Mağaza atmosferinin tüketici tercihindeki önemi. The Journal of Social Science, 1(2), 94-103.

Byrne, B. M. (2001). Structural Equation Modeling with AMOS, Mahwah, NJ, Lawrence Erlbaum.

Chang, H. J., Yan, N.R. and Eckman, M. (2014). Moderating effects of situational characteristics on impulse buying, International Journal of Retail And Distribution Management, 42(4), 298-314.

Chang, J.H., Eckman, M. and Yan, N. R. (2011). Application of the Stimulus-Organism-Response model to the retail environment: The role of hedonic motivation in impulse buying behavior, The International Review of Retail, Distribution and Consumer Research, 21(3), 233-249.

Chen, H. and Hsieh, T. (2011). The effect of atmosphere on customer perceptions and customer behaviour responses in chain store supermarkets, African Journal of Business Management, 5(24), 10054-10066. 


\section{V. Ö. Akgün - M. Zerenler 13/3 (2021) 2110-2128}

Coşkun, T. ve Marangoz, M. (2019). Hedonik ve faydacı tüketim davranışları ölçeğinin geliştirilmesi: güvenirlik ve geçerlik çalışması, Business and Economics Research Journal, 10(2), 517-539.

Çoban, S. ve Keskin, S. (2018). Internet bankacilı̆̆ında hedonik motivasyon unsurları, e-tatmin ve e-bağlllık etkileşimi: Nevşehir ili örneği, Erciyes Üniversitesi İktisadi ve İdari Bilimler Fakültesi Dergisi, 52, 93-114.

D'astous, A. (2000). Irritating aspects of the shopping environment, Journal of Business Research, 49(2), 149-156.

Eroglu, S., Machleit, K. and Davis, L. (2001). Atmospheric qualities of online retailing: A conceptual model and implications, Journal of Business Research, 54(2), 177-184.

Feattahlıŏ̆lu, S. (2014). Tüketicilerin mağaza atmosferinden etkilenme düzeylerinin demografik faktörler açısından incelenmesi, Akademik Araştırmalar ve Çalışmalar Dergisi, Journal of Academic Researches and Studies, 6(11), 27-40.

Fettahlığlu, H. S. (2014). Tüketicilerin mağaza atmosferinden etkilenme düzeylerinin demografik faktörler açısından incelenmesi, Akademik Araştırmalar ve Çalışmalar Dergisi, 6(11), 27-40.

Garlin, F.V. and Owen, K. (2006). Setting the tone with the tune: A meta-analytic review of the effects of background music in retail settings, Journal of Business Research, 59(6), 755-764.

Hair, J. F., Hult, G.T., Ringle, C. M. and Sarstedt, M. (2014). A Primer on partial Least Squares Structural Equation Modelling. Thousands Oak: Sage

Hanai, T. and Oguchi, T. (2009). How do consumers perceive the reliability of online shops? Cyber psychology: Journal of Psychosocial Research on Cyberspace, 3(2), Erişim Adresi: http://cyberpsychology.eu/view.php?cisloclanku=2009111002\&article=6. Erişim Tarihi: 02.01.2021.

Hetharie, A. J., Surachman, Hussein, S.S. and Puspaningrum, A. (2019). SOR (Stimulus-Organism-Response) model application in observing the influence of impulsive buying on consumer"s post-purchase regret, International Journal of Scientific and Technology Research, 8(11), 2829-2841.

Hoch, J. S. and Loewenstein, F.G. (1991). Time-inconsistent preferences and consumer self-control, Journal of Consumer Research, 17(4), 492-507.

Houston, M. and Rothschild, L. M. (1974). A Paradigm for Research On Consumer Involvement, University of Wisconsin, Graduate School of Business, Madison, WI.1-35.

Hui, M. K., Dube, L. and Chebat, J. C., (1997). The impact of music on consumers' reactions to waiting for services, Journal of Retailing, 73(1), 87-104.

Ilmi, Z., Darma, C. D. and Wijayanti, C.T. (2020). Can servqual mediate from the store atmosphere and customer satısfaction? Management Theory and Studies for Rural Business And Infrastructure Development, 42(3), 359-368

Indra, A. W. (2014). Pengaruh store atmosphere terhadap kepuasan konsumen, Jurnal Administrasi Bisnis,14(1), 1-7.

Iyer, R. G., Blut, M., Xiao, H.S. and Grewal, D. (2020). Buying: A meta-analytic review, Journal of Theacademy of Marketing Science, 48, 384-404.

İslamoğlu, A. H. ve Alnıaçık, Ü. (2016). Sosyal Bilimlerde Araştırma Yöntemleri, İstanbul, Beta Yayıncılık.

Jani, D., and Han, H. (2014). Testing the moderation effect of hotel ambience on the relationships among social comparison, affect, satisfaction, and behavioural intentions, Journal of Travel and Tourism Marketing, 31 (6), 731-746.

Karagöz, Y. (2006). SPSS 23 ve AMOS 23 Uygulamalı İstatistiksel Analizler, Ankara, Nobel Yayınevi.

Kotler, P. (1973). Atmospherics as a marketing tool, Journal of Retailing, 4(9), 48-64.

Kotler, P. (1974). Atmospherics as a Marketing Tool, Journal of Retailing, 49(4), 48-61.

Kotler, P. (2000). Marketing Management, New Jersey, Millenium Edition, Prentice Hall, Upper Saddle River.

Kusumowidagdo, A., Sachari, A. and Widodo, P. (2012). The impact of atmospheric stimuli of stores on human behavior, Procedia - Social and Behavioral Sciences, 35, 564-571.

Küçükahmet, L. (2000). Program Geliştirme ve Öğretim, İstanbul, Nobel Akademik Yayıncılık. 


\section{V. Ö. Akgün - M. Zerenler 13/3 (2021) 2110-2128}

Mamuaya, I.C.N. (2018). The effect of sales promotion and store atmosphere on hedonic shopping motivation and impulsive buying behavior in hypermart Manado City, Development Research of Management Jurnal Manajemen-DeReMa, 13(1), 83-99.

Mattila, A. S. and Wirtz, J. (2001). Congruency of scent and music as a driver of in-store evaluations and behavior, Journal of Retailing, 77(2), 272-289.

Mattila, A.S. and Wirtz, J. (2008). The role store environmental stimulation and factors on impulse purchasing, Journal of Services Marketing, 22(7), 562-567.

Mehrabian, A., and Russel, J.A. (1974). An Approach to Environmental Psychology, Cambrige, Mass: MIT press.

Melia, M. and Carida, A. (2020). Designing in-store atmosphere for a holistic customer experience. In Handbook of Research on Retailing Techniques for Optimal Consumer Engagement and Experiences. (Eds. F. Musso and E.Druica). 87-109. DOI: 10.4018/978-1-7998-1412-2.ch007.

Meydan, H. C. ve Şeşen, H. (2015). Yapısal eşitlik modellemesi, Ankara, Detay Yayıncılık.

Michon, R., Chebat, C.J. and Turley, W.L. (2005). Mall atmospherics: The interaction effects of the mall environment on shopping behavior, Journal of Business Research, 58, 576-583.

Mufarrofah, U. and Yuniati, T. (2016). Pengaruh atribut produk, motif hedonic dan motif utilitarian terhadap keputusan pembelian, Jurnal Ilmu dan Riset Manajemen, 15(1),102-121.

Nusairat, M. N. (2015). The effect of shopping environment on Jordanian mall customers' behaviour: The mediating role of customers' emotions and cognition. Salford Business School. College of Business and Law, University of Salford, Salford, UK Submitted in Partial Fulfilment of the Requirements of the Degree of Doctor of Philosophy.

Odabaşı Y. ve Barış, G. (2002). Tüketici Davranışı, İstanbul, Mediacat Yayınları.

Önen, V. (2019). Tüketici motivasyonları ile sosyal medyanın tüketici davranışına etkisinin satın alma niyetine etkisinin hava yolu yolcu taşımacılığında incelemesi, İşletme Araştırmaları Dergisi-Journal of Busıness Research-Turk, 11(3), 1866-1882.

Öz, M. ve Mucuk, S. (2015). Tüketici satın alma davranışı kapsamında hedonik (hazc1) tüketimin plansız alışveriş üzerine etkilerinin incelenmesi, Pazarlama Teorisi ve Uygulamaları Dergisi, 1(2), 37-60.

Pitt, M. and Musa, Z. N. (2009). Towards defining shopping centres and their management systems, Journal of Retail and Leisure Property, 8(1), 39-55.

Porral, C.C. and Mangin, L.P.J. (2021). Examining the influence of store environment in hedonic and utilitarian shopping, Administrative Sciences, 11(6), 1-15.

Putra, I.R.T., Aprilia, C. and Aulia, A. (2019). The role of store atmosphere on purchase decision: Case of cafes in banda aceh, Management \& Economics Review, 4(2), 109-117.

Rook, D. W., and Hoch, S. J. (1985). Consuming Impulses. Hirschman, E. C. and Holbrook, M. B. (Eds), Advances in Consumer Research, 23-27, Chicago.

Rook, D.W. and M.P. Gardner. (1993). Inthemood: Impulse buying's affective antecedents, Research in Consumer Behavior, 6, 1-2.

Ryu, K. and Jang, S., (2008). Influence of Restaurants' Physical Environment on Emotion and Behavior Intention, The Service Industries Journal, 28(8), 1151-1165.

Sekeran, U. (2003). Business Research Methods: A Skill-Building Approach, John Wiley\&Sons.

Soysal, S. (1999). Mağazacılık: Mükemmel Müşteri Hizmeti ve Etkili Satış Teknikleri, İstanbul, Remzi Kitabevi.

Spangenberg, E. R., Grohmann, B. and Sprott, D. E. (2005). It's Beginning to Smell (and Sound) a Lot Like Christmas: The interactive effects of ambient scent and music in a retail setting, Journal of Business Research, 58(11), 1583-1589.

Spangenberg, R.E., Sprott, E.D. and Tracy, L. D. (2006). Gender-congruent ambient scent influences on approach and avoidance behaviors in a retail store, Journal of Business Research, 59(12), 1281-1287.

Şimşek, Ö. F. (2007). Yapısal Eşitlik Modellemesine Giriş: Temel İlkeler ve Lısrel Uygulamaları, İstanbul, Ekinoks Eğitim Danışmanlık Hizmetleri.

Tek, B. Ö. ve Demirci, F. (2006). Perakende Pazarlama Yönetimi, İzmir, Birleşik Matbaacılık. 


\section{V. Ö. Akgün - M. Zerenler 13/3 (2021) 2110-2128}

Tokgöz, E. (2018). Materyalist değerler statü tüketimi ve dürtüsel satın alma arasındaki ilişki, Yönetim ve Ekonomi Araştırmaları Dergisi, 16, Özel Sayı, 1-19.

Turley, L. W., and Milliman, R. E. (2000). Atmospheric effects on shopping behavior: a review of the experimental evidence, Journal of Business Research, 49,193-211.

Ünal, S. ve Ceylan, C. (2008). Tüketicileri hedonik alışverişe yönelten nedenler: İstanbul ve Erzurum illerinde karşılaştırmalı bir araştırma, Atatürk Üniversitesi, İktisadi ve İdari Bilimler Dergisi, 22(2), 265-283.

Verplanken, B. and Herabadi, A. (2001). Individual differences in impulse buying tendency: Feeling and nothinking, European Journal of Personality, 15(1), 71-83.

Villi, B. ve Kayabaşı, A. (2013). Kozmetik ürünlerde kadınların dürtüsel satın alma davranışlarını etkileyen faktörlerin analizi, Ekonomik ve Sosyal Araştırmalar Dergisi, 9(9), 143-165.

Vohs, K. D. and Faber, R. J. (2007). Spent resources: Self-regulatory resource availability affects impulse buying, Journal of Consumer Research, 33(4), 537-547.

Wang, X., Ali, F., Tauni, Z.M., Zhang, Q. and Ahsan, T. (2021). Effects of hedonic shopping motivations and gender differences on compulsive online buyers, Journal of marketing theory and practice, 1-17.

Watson, D. and Tellegan, A (1985). Towards a consensus structure of mood, Psychological Bulletin, 98(2), 219235.

Yim, C.M., Yoo, C.S., Sauer, L.P. and Seo, H.J. (2014). Hedonic shopping motivation and co-shopper influence on utilitarian grocery shopping in superstores, Journal of the academic Marketing Science, 42, 528-544.

Yoo, C., Park, J. and MacInnis, D. J. (1998). Effects of store characteristics and in-store emotional experiences on store attitude, Journal of Business Research,42(3), 253-263.

Yulisetiarini, D. and Mawarni, D.T. (2021). The influence of service quality, brand image, and store atmosphere on customer loyalty through customer satisfaction at indomaret plus jember, Quality Management, 22(181), 101-105.

Yüksekbilgili, Z. (2016). Hızlı moda tüketicilerinin mağaza atmosferine verdikleri önemin ölçülmesi için bir ölçek geliştirme çalışması: Avrasya mağaza atmosfer ölçeği, The Journal of Academic Social Sciences, 30(30), 444-473. 